NBER WORKING PAPER SERIES

\title{
BIOLOGICAL INNOVATION AND PRODUCTIVITY GROWTH IN THE ANTEBELLUM COTTON ECONOMY
}

\author{
Alan L. Olmstead \\ Paul W. Rhode \\ WORKING PAPER 14142 \\ http://www.nber.org/papers/w14142 \\ NATIONAL BUREAU OF ECONOMIC RESEARCH \\ 1050 Massachusetts Avenue \\ Cambridge, MA 02138 \\ June 2008
}

A number of talented students have contributed to the collection and analysis of the data. Heading this list are Jeffery Graham and Janine L. F. Wilson who have served as the project's lead research assistants. Amir Amadi, Raphael Avraham, Audrey Goodwater, Rowena Gray, Pablo Jenkins, Teresa Nguyen, and Joanna Parks at UC Davis; Edward Esau of UC Riverside and the Historic Natchez Foundation; Tiffany Hamelin, University of Mississippi; Peter Malaspina, University of North Carolina; Jeremy Meiners, Washington University; Kristi Barnes, Auburn University; and Eric Sumral, Millsaps College, have all spent countless hours poring over plantation records. We give special thanks to Shelagh Mackay, whose attention to detail and insights have left a positive mark on our research. Librarians across the South have been of great assistance in identifying sources. We would like to recognize Henry Fulmer, South Caroliniana Library, University of South Carolina; Laura Clark Brown, Southern History Collection, University of North Carolina; Elizabeth Dunn and Linda McCurdy, Duke University; Tara Z. Laver, Louisiana State University; Andrea Cantrell, University of Arkansas; Donnelly Lancaster, University of Alabama; Melissa Smith, Tulane University; Burt Altman, Florida State University; Clinton Bagley, Mississippi Department of Archives and History; and Jennifer Ford, University of Mississippi, for their special efforts. Mimi Miller at the Historic Natchez Foundation has been a font of information. Dale Flesher and Mary Jones both graciously opened their private records to us. We have benefited from the comments, assistance, and interest of Julian Alston, Lety Arroyo-Abad, Jeremy Atack, Louis Cain, Lee Craig, 
Gregory Clark, Peter Coclanis, Stanley Engerman, Price Fishback, Timothy Guinanne, Mary Jackman, Zorina Khan, Thomas Mayer, Stephanie McCurry, John Hebron Moore, Joel Mokyr, Chiaki Moriguchi, Thomas Mroz, Carl Pray, Richard Steckel, Richard Sutch, and Gavin Wright, as well as participants at our presentations at UC Davis and UC Riverside, Duke, Northwestern, Stanford, Vanderbilt, and Yale universities, the NBER-DAE Summer Institute, and the universities of Arizona, Athens, Carlos III, Pennsylvania, and Zaragoza and two anonymous referees. This research is supported by National Science Foundation Collaborative Research Grants, "Seeds and Slaves: Technological Change, Plantation Efficiency, and Southern Economic Development," SES0550913 and SES-0551130. The views expressed herein are those of the author(s) and do not necessarily reflect the views of the National Bureau of Economic Research.

(C) 2008 by Alan L. Olmstead and Paul W. Rhode. All rights reserved. Short sections of text, not to exceed two paragraphs, may be quoted without explicit permission provided that full credit, including $($ ) notice, is given to the source. 
Biological Innovation and Productivity Growth in the Antebellum Cotton Economy Alan L. Olmstead and Paul W. Rhode

NBER Working Paper No. 14142

June 2008

JEL No. J43,N11,N5,O3

\begin{abstract}
$\underline{\text { ABSTRACT }}$
The Cliometrics literature on slave efficiency has generally focused on static questions. We take a decidedly more dynamic approach. Drawing on the records of 142 plantations with 509 crops years, we show that the average daily cotton picking rate increased about four-fold between 1801 and 1862. We argue that the development and diffusion of new cotton varieties were the primary sources of the increased efficiency. These finding have broad implications for understanding the South's preeminence in the world cotton market, the pace of westward expansion, and the importance of indigenous technological innovation.
\end{abstract}

\author{
Alan L. Olmstead \\ Institute of Governmental Affairs \\ UC, Davis \\ Davis, CA 95616 \\ alolmstead@ucdavis.edu \\ Paul W. Rhode \\ Economics Department \\ Eller College of Management \\ University of Arizona \\ Tucson, AZ 85721-0108 \\ and NBER \\ prhode@email.unc.edu
}




\section{Biological Innovation and Productivity Growth in the Antebellum Cotton Economy}

American slavery has long fascinated scholars. Over the past 40 years few issues have so sharply divided cliometricians as the performance and nature of the slave economy. These debates have generally focused on static questions such as the relative efficiency of slave and free-labor enterprises. Much of this research has relied on the Parker-Gallman sample which provides a cross-sectional view of cotton farms and plantations as recorded in the 1859 census. We take a decidedly more dynamic approach. Our goal is to explain the forces which propelled the rapid expansion of the American cotton economy and made the South the world's dominant producer of the Industrial Revolution's key raw material. In doing so we place the history of slavery and cotton plantations into the context of the more general literature on the sources of American productivity growth.

Standard accounts treat the technology of cotton production as static following the invention and refinement of Eli Whitney's 1793 saw gin. Given that cotton cultivation remained a hand labor task throughout the slavery period and that no machines comparable to the reaper gained acceptance, this view seems plausible at first glance. All early attempts to develop mechanical cotton harvesters failed. The stereotype of an “uninventive South” is reinforced by the region’s low level of patenting activity. Implicit in this treatment is the assumption that all Upland cotton was alike. But cotton was not cotton. The qualitative accounts of planter-historian B. C. L. Wailes, agronomist J. O. Ware, historian John Hebron Moore, and others, asserted that southern planters created superior cotton varieties that significantly increased cotton yields, fiber quality, and the amount of cotton that could be picked in a day.

The surviving archival records of 142 plantations allow us to construct a panel dataset including 509 crop years and 704,800 daily observations of the cotton production activities of 6,200 individual enslaved African Americans. The data clearly document the revolution in cotton picking efficiencybetween 1801 and 1862 the average amount of cotton picked per slave in a day quadrupled. This rapid 
growth in picking efficiency — 2.3 percent per annum—-was substantially faster than the advance in labor productivity in the overall economy.

Although many have declared this period of the South's history bereft of indigenous technological advances, the region was the undisputed world leader in the creation of superior cotton varieties. Despite concerted efforts, the British were unable to replicate the results in their far-flung colonial empire. The achievements of antebellum southern cotton breeders well surpassed those of northern wheat breeders. Our findings shed light on these advances in cotton breeding, as well as the movements in slave, cotton, and land prices; the factors responsible for the growth of cotton output and the spread of cotton cultivation; the sources of the differences in regional production and productivity between the Old and New South; as well as the conventional static comparisons of plantation and nonplantation efficiency.

The paper takes the following form. First, we explore the macro trends in the antebellum cotton economy. The data on cotton and slave prices, coupled with the observation that cotton output was growing at a faster pace than the labor force in the cotton-producing counties, suggest that labor productivity was rising between 1800 and 1860 . These macro trends suggest a dynamic South. Contemporaries, and many historians, viewed the introduction and improvement of large-boll cottons from Mexico as a revolutionary innovation that rivaled the importance of Whitney's gin. We follow this lead by analyzing the creation and diffusion of Upland cotton varieties. Next, we introduce a new dataset drawn from the archival records of 142 plantations. These data show that the amount of Upland cotton the typical slave picked in a day increased approximately four times in the 60 years preceding the Civil War. We go on to explore a number of hypotheses for the increase in picking efficiency, concluding that improved cotton varieties likely accounted for most of the change. We further argue that our measured increase in picking efficiency captures only part of the impact of biological innovation on cotton production because the new varieties also offered higher yields and rendered higher quality fiber than most earlier cottons. Finally, we note that due to increasing insect and disease problems, cotton yields and picking efficiency would have likely fallen in the absence biological innovation. 


\section{Neglected Signs of Rapid Productivity Growth}

Figure 1 plots the long-run trends in cotton production (in logs) along with the real prices of both cotton and prime-age male slaves. The data depict a dynamic and expanding economy. From 1800 to 1860, the quantity of cotton produced increased by 6.6 percent per annum as the real price of cotton fell by 0.5 percent per annum. Over a slightly shorter period beginning in 1804, the U.S. slave population rose by 2.4 percent while the real price of prime-age male slaves rose by 1.9 percent per year. Obviously not all slaves worked in cotton and not all cotton was produced by slaves (although by the 1850s the overwhelming bulk of the crop was). ${ }^{1}$ We can develop refined estimates of the cotton labor force by totaling the Lee A. Craig and Thomas Weiss numbers of agricultural workers (both slave and free) for only those counties producing cotton commercially. ${ }^{2}$ As the growth rates for slaves and for all workers in Table 1 indicate, cotton output expanded faster than the number of workers over the 1800-60 period and for each of the subperiods, 1800-20, 1820-40, and 1840-60. For the entire antebellum era, the gap between the growth rates of cotton output and the enslaved agricultural labor force in cotton counties averaged 2.4 percent per annum. Hints of rising labor productivity also appear on the dual-side (costfunction) of the production function. Slaves were a major input in the production of cotton, yet their real prices were soaring at a time when real cotton prices were declining.

In Time on the Cross, Robert Fogel and Stanley Engerman recognized that productivity was rising: "The basic cause of this long-term decline [in cotton prices] was the steady increase in productivity. Among the developments which made cotton farming increasingly more efficient were the improvements in the varieties of cottonseeds, the introduction of the cotton gin, the reduction in

\footnotetext{
${ }^{1}$ Foust, Yeoman Farmer, pp. 161, 233-37, reported that slave plantations produced roughly 95 percent of American cotton in the 1850s.

${ }^{2}$ Craig and Weiss, Rural Agricultural Workforce. To identify the cotton counties for the 1800-40 period, we used the well-known cotton production maps of O. C. Stine and O. E. Baker, USDA, Atlas, pt. 5, sec. A, pp. 16-17, and used Census of Agriculture data for the 1840-60 period as reported in Craig, Haines, and Weiss, Development, Health, Nutrition, and Mortality, and U.S. Censuses of Agriculture. Following Foust, Yeoman Farmer, we restricted the Census counties to those reporting 1,000 or more 400-lb. bales. For a discussion of these maps see Whartenby, Land and Labor Productivity, pp. 60-61.
} 
transportation and other marketing costs, and the reallocation of cotton production in the more fertile lands of the New South.”3 This brief passage is the only acknowledgement we have found in the post1970 cliometrics literature of the impact of new cotton varieties. In subsequent cliometrics exchanges, the quest to understand the sources and timing of productivity growth in the southern cotton economy, as well as its role in making the region the dominant world supplier, took a backseat to addressing static questions such as the self-sufficiency of southern plantations, the distribution of wealth, and the relative efficiency of slave and free-labor farms. This emphasis was in part due to the heavy lifting done by William Parker, Robert Gallman, and their students in constructing the 1859 Census micro-sample. ${ }^{4}$

A handful of agricultural and economic historians have touched on the issue of long-run productivity growth. Noting the divergent movement of cotton and slave prices, Alfred H. Conrad and John R. Meyer hinted to the importance of productivity increases, which they attributed to the movement of cotton production to more fertile western lands. ${ }^{5}$ Building on a long tradition of agricultural writers, John Hebron Moore argued that antebellum southern planters developed and adopted a succession of new cotton varieties that increased yields per acre, quality, disease resistance, and picking efficiency. ${ }^{6}$ Drawing on a limited sample, Franklee Whartenby estimated that between 1800 and 1840 cotton yields per acre increased 46 to 78 percent and suggested that improved varieties allowed slaves to pick much cotton in a day. "With the advent of Petit Gulf cotton in the late 1820's, the daily picking averages jumped from about fifty or sixty to about 125 to 150, with as much as 300 or more sometimes reported.”7 Stanley Lebergott also called attention to a change in picking rates. Relying on an assortment of retrospective secondary sources, he surmised that the amount of cotton harvested in a day increased from

\footnotetext{
${ }^{3}$ Fogel and Engerman, Time on the Cross, pp. 91-93, and Without Consent, pp. 71, 95. For a more general statement regarding productivity changes see Fogel and Engerman, “Explaining the Relative Efficiency,” p. 282.

${ }^{4}$ Parker and Gallman, Southern Farms Study, 1860.

${ }^{5}$ Conrad and Meyer, Economics of Slavery, pp. 75-78.

${ }^{6}$ Moore, “Cotton Breeding,” p. 96, Agriculture, pp. 13-36, and Emergence, pp. 30-34. Moore built on the work of a number of prominent historians including B. C. L. Wailes, Report, James L. Watkins, King Cotton, and Louis Cecil Gray, History.

${ }^{7}$ Whartenby, Land and Labor Productivity, pp. 54, 104-05.
} 
50 pounds in 1800 to 200 pounds in the 1850 s. $^{8}$ The cliometrics literature has all but ignored these claims of sustained productivity advances. There has been little appreciation of how the evolution of cotton varieties helped shape southern development.

\section{The Creation of American Upland Cotton Varieties}

The dynamism of the cotton-producing sector bears directly on the very foundations of the Industrial Revolution. ${ }^{9}$ The usual story focuses on the inventions of Richard Arkwright, Samuel Crompton, James Hargreaves, and John Kay, which mechanized spinning and weaving. Homage is also paid to Eli Whitney whose saw gin helped ensure a supply of raw cotton to meet growing industrial demands. ${ }^{10}$ However, this account neglects another set of innovators- the farmers and plant breeders who developed cotton varieties suited to the new spinning technologies and, as importantly, to the diverse North American environment.

According to Ware, the varieties that became the basis for the South's economic development were a local invention, a distinctive "Dixie product.” “Although the stocks of the species were brought from elsewhere, new types, through [a] series of adaptational changes, formed this distinctive group the final characteristics of which are a product of the Cotton Belt of the United States.”11 The cottons that came to be cultivated in the United States belonged to one of two species. Sea Island (Gossypium barbadense) was grown primarily along the coasts and on the offshore islands of Georgia, South Carolina, and Florida. Cottons of the second and more important species (Gossypium hirsutum) were

\footnotetext{
${ }^{8}$ Lebergott, Americans, pp. 168, 176-77. Also see Parker, “Labor Productivity,” p. 235. Campbell, “Gender Division," emphasized the importance of new varieties in the southeast. Relying on Moore, Hayami and Ruttan, Agricultural Development, p. 209, also alluded to productivity enhancing innovations. The only other reference to biological innovation in antebellum cotton production we found in the economic history literature appears in Scheiber, Vatter, and Faulkner, American Economic History, p. 131.

${ }^{9}$ This section and the next extend the analysis in Olmstead and Rhode, Creating Abundance, chapter 4.

${ }^{10}$ Landes, Unbound Prometheus, p. 202. Lakwete, Inventing the Cotton Gin, pp. 1-96, made a strong case that the ginning bottleneck was not as severe as generally thought.

${ }^{11}$ Ware, “Origin,” p. 1. Modern plant scientists concur with Ware's general assessment. See Poehlman and Sleper, Breeding Field Crops, pp. 374-76.
} 
commonly referred to as Upland cottons because they were grown in the more variable climates away from the coast. None of these cottons were native to British North America. ${ }^{12}$

In its native environment in Central America, Upland cotton was a frost-intolerant, perennial shrub with short-day photoperiod response. It flowered in the late summer and autumn. At more northern latitudes of the American South, the conditions that triggered flowering occurred later in the year, but the first frost typically hit before the cotton could mature. Initial attempts to grow Upland cotton in the areas that now constitute the United States faced severe difficulties. Success depended on finding a mutation/cross or introducing a variety with the appropriate photosensitivity characteristics. ${ }^{13}$ Adaptation was assisted by the genetic heterozygosity of the initial imports which made them relatively malleable. The varieties that eventually prevailed in the United States flowered in early to mid-summer and began to mature by the end of August or early September. The process of molding Upland cotton to the environment was repeated again and again. According to Ware, cotton-producing technologies were never static. "The vast differences in climate and soil that obtain over the Cotton Belt undoubtedly brought about a kind of natural selection which eliminated many of the kinds that were tried, while others became adapted to the several conditions under which they were grown and selected over a period of years.”14 These new American Upland cotton varieties proved "much more suitable, than any other kind, for general factory use.”15

\footnotetext{
${ }^{12}$ Modern genetic research recognizes 50 species of cotton (genus Gossypium) of which four major species were domesticated independently in different parts of the world. G. hirsutum (Upland cotton), which accounts for about 90 percent of world production, originated in southern Mexico and Guatemala. It was probably first domesticated in Yucatan and then adapted by generations of farmers for the Mexican highlands. The origin of G. barbadense (Sea Island cotton) is debated, with Brazil, the Caribbean, and Peru being the leading contenders. The two Old World species, G. arboretum and G. heraceum originated in Africa and Asia. Genetic studies of 50 Upland cultivars grown in the United States in the 1990s showed the overwhelming influence of Mexican and Guatemalan G. hirsutum. Wendel, Brubaker, and Percival, “Genetic Diversity,” pp. 1291-1310; Brubaker and Wendel, "Reevaluating the Origin,” pp. 1309-26; Brubaker, Bourland, and Wendel, "Origin and Domestication of Cotton,” pp. 3-31; Fryxell, Natural History; and Wendel and Cronn, "Polyploidy,” pp. 139-86.

${ }^{13}$ Stephens, "Some Observations," pp. 409-18; Purseglove, Tropical Crops, pp. 340, 345, 352-54.

${ }^{14}$ Ware, “Plant Breeding,” p. 659. Also see Handy, “History,” pp. 17-66.

${ }^{15}$ Ware, “Origin,” pp. 1-2. This American advantage changed over time as varieties developed in the United States were adopted in other regions.
} 
The most common Upland variety in the colonial period was Georgia Upland (aka Green Seed, Georgia Green Seed), which was introduced to North America in 1733/34. By later standards, Georgia Green Seed was a low quality, low yielding, low value, short staple variety that was hard to pick. Its seeds were "fuzzy," meaning that the lint clung to the seed, making their separation difficult. Whitney’s achievement was to develop a saw gin that could economically remove these seeds. ${ }^{16}$ Upland cottons evolved as farmers acclimatized the standard Georgia Green Seed to different conditions. By the end of the eighteenth century an improved variety, Tennessee Green Seed, had been developed in the Cumberland Valley, and by 1801 seed for this variety was being grown in South Carolina and advertised for sale as far away as Savannah. It was lauded as being easier to pick and earlier to mature. ${ }^{17}$

There were two parallel development paths, one focused on Sea Island varieties and the other on Creole Black Seed varieties. In the late eighteenth century (1786 is a commonly cited date), Georgia planters introduced high quality cottons from the Caribbean (or possibly Brazil). ${ }^{18}$ After considerable effort, some of these plants were acclimatized to become the Sea Island cottons. Sea Island types were low yielding and difficult to pick, but they produced a longer, finer fiber than Upland varieties, and their

\footnotetext{
${ }^{16}$ Again, see Lakwete, Inventing the Cotton Gin, for an assessment of Whitney's contribution. Variants of Upland cotton could have naked, black seeds much like Sea Island cotton. But these Upland strains were typically less productive and more disease-prone than the green or brown fuzzy seeded variants. A small number of alleles controlled these characteristics and the black trait is recessive. Thus, while it would be technically possible to produce an Upland crop that did not need a saw gin (or its equivalent), it would be associated with lower yields and subject to "invasion" by Green Seed germplasm. In Green Seed cotton, black seeds would occasionally appear (as Mendel's laws predict). Tyler, "Varieties," p. 17, stated that growers and breeders generally believed that "entirely naked seeds should be picked out and discarded from choice seed intended for planting." He further reported the results from a test comparing fuzzy and naked seed from the same row of plants, which revealed that the plants grown from fuzzy seed yielded 40 percent lint whereas those from naked seeds yielded 28 percent.

${ }^{17}$ Watkins, King Cotton, pp. 100, 254; Ware, “Plant Breeding,” pp. 658-59; Kilpatrick, “Historical and Statistical Collections,” pp. 632-33; 1 November 1801, 1801-1812 Register Book, Guignard Family Papers, South Caroliniana Library, University of South Carolina [hereafter SCL/USC]; Georgia Gazette (30 April 1801), p. 1. The seller of the Cumberland seed noted that it produced a low bushy cotton that was of inferior quality to Sea Island but had the virtue of "generally producing one month earlier than the former."

${ }^{18} \mathrm{~A}$ widely accepted account is based on a letter from Patrick Walsh of Jamaica who asserted that he sent three sacks of seed to Frank Leavet (sometimes spelled Levett). Donnell, Chronological and Statistical History, p. 48. Smith's account, Crop Production, p. 296, of the introduction of Sea Island suggested that the variety was native to Brazil. There are at least four other contemporary claims of first introduction. See Watt, Wild and Cultivated Cotton Plants, pp. 16-17; Stephens, “Origin of Sea Island Cotton,” pp. 391-99; Rosengraten, Tombee, p. 50; and Lakwete, Inventing the Cotton Gin, p. 24. Porcher and Fick, Story of Sea Island Cotton, pp. 93-99, concluded that the "plants of Gossypium barbadense that came to be called sea island cotton originated in 1786 with its conversion to dayneutral flowering.”
} 
smooth black seeds could be removed easily with a roller gin-a machine widely available in the colonies. Persistent attempts to extend the range of Sea Island by acclimatizing it to grow away from the coast met with little success.

As with Upland cottons, Sea Island cottons were genetically diverse and mutable. South Carolina planter Whitemarsh Seabrook noted in 1846 that decades of breeding had resulted in up to 15 subvarieties of Sea Island cotton. ${ }^{19}$ Ware asserted that "more than one species and no doubt several varieties were brought in during the early period. ... From these introductions the sea-island growers doubtless developed their own distinct varieties and strains. ${ }^{20}$ Just as the early mechanical inventors whose genius stimulated the Industrial Revolution knew little of the laws of mechanics, "these early breeders knew little of genetics or the science of plant breeding, but they were artists in knowing their plants. They sought practical ends and concentrated on the development of the long silky types of cotton that the English spinners of the time demanded. . . The result was the development of many special strains of the finest cotton the world has ever known.,21

Historians usually depict crops and farm technologies as spreading from east to west, but French colonists in the Mississippi Valley actually began continuous commercial production of cotton before planters in the Carolinas and Georgia. During the early 1720s, French settlers experimented with Sea Island cottons with limited success in a narrow band along the Gulf. The repeated failure of Sea Island elsewhere led farmers to test other options. By 1733 a new variety had been imported from Siam. Dubbed Black Seed, or Creole, it soon became the dominant cotton in the region. In the early nineteenth century, lower Mississippi Valley planters considered Creole their “native” cotton. Like Sea Island, it had smooth seeds that could be extracted with a roller gin. Creole was far more reliable and out-yielded Sea Island in this area but produced lower quality fiber. As with Sea Island, Creole was difficult to pick due to its small bolls and because the lint clung to the pods. But Creole was superior in many respects to the Green Seed

\footnotetext{
${ }^{19}$ Chaplin, Anxious Pursuit, p. 221.

${ }^{20}$ Ware, "Plant Breeding,” p. 658. Also, Rosengraten, Tombee, p. 76.

${ }^{21}$ Ware, "Plant Breeding," p. 658.
} 
Upland cottons and commanded a higher price. ${ }^{22}$ The Black Seed varieties first developed in the Gulf States moved eastward and mixed with local stocks of Black and Green Seed to create an array of varieties of differing quality and ripening characteristics. In the first two decades following Whitney’s 1793 invention, Southeastern planters experimented with myriad varieties to find suitable stock for their local conditions. ${ }^{23}$

\section{The Introduction of Mexican Cotton}

The first in a long chain of events that would revolutionize southern cotton production occurred in 1806. While visiting Mexico City, Walter Burling obtained seeds of a high quality cotton which he passed on to his Natchez neighbor, William Dunbar, for experimentation. This "required some reselection for adaptation before satisfactory responses under Mississippi Valley conditions were obtained. Fresh seed from Mexico during the first year or two of planting was said to produce no more than one-half crop. ${ }^{24}$ By 1808, Dunbar sent samples of fiber to Liverpool to be tested for spinning quality and received a positive response. $^{25}$

By 1820, southern breeders had out-crossed Mexican highland cotton with Green Seed, Creole, and possibly even Sea Island varieties, creating many new genotypes. ${ }^{26}$ Word of the new white-seeded cottons had already reached Baltimore by 1820 because an article in the American Farmer noted that the new “Mexican cotton” variety was “found to ripen, in a greater degree at one time: has a shorter season

\footnotetext{
${ }^{22}$ Moore, Agriculture, pp. 13-36.

${ }^{23}$ For an example of the interregional exchange of cotton seeds see, Edmund Bacon of Augusta to Joseph Pannile of Natchez, 3 December 1807, and Edmund Bacon to Agnes Pannile of Natchez, 24 December 1815, Edmund Bacon Letters, Mss. 2178, Louisiana and Lower Mississippi Valley Collections, LSU Libraries. For a description of seed varieties and planter attention to detail, see records for 1788 in the Elias Lynch Rivers Family Papers, 51-542, South Carolina Historical Society; and Lewis Du Pre, Observations on the Culture of Cotton, pp. 6-7. Also, Moore and Moore, Cotton Culture, pp. 4-36, and telephone interview with John Hebron Moore, 20 April 2005.

${ }^{24}$ Ware, “Origin,” p. 50.

${ }^{25}$ Dunbar to Green \& Wainewright, 2 October 1807, Dunbar, Life, p. 356, also pp. 357, 360, 388-90; Moore, “Cotton Breeding,” pp. 95-104, and Agriculture, pp. 32-33; Gray, History, pp. 673-77; Collings, Production of Cotton, p. 201; and Watkins, King Cotton, p. 165. The papers of John Minor, a Natchez-area planter, include letters (2 May 1817 and 17 September 1820) from Liverpool factors mentioning Dunbar cotton as a distinct type trading at premium prices, in the Minor Family Papers, Coll. 1564, Southern Historical Collection, Wilson Library, University of North Carolina at Chapel Hill [hereafter SHC/UNC].

${ }^{26}$ Smith, Crop Production, pp. 296-97.
} 
than any other cotton known among us: and is collected in much greater quantities, by a labourer, in one day. The cotton wool is represented to hang out of the pods of this species of the plants, and even to drop at times from them. ${ }^{27}$ In addition, contemporaries lauded the Mexican cotton for out-yielding Creole and Green Seed and for producing a fiber superior to the latter. Perhaps most importantly, at least initially it was relatively resistant to a disease called "the rot” which was causing large losses throughout the South. $^{28}$

On top of all of these qualities, Mexican cotton (and subsequent Mexican hybrids) had higher lint-to-seed ratios than the varieties they replaced. According to Lewis Cecil Gray, "the older varieties yielded lint weighing only 25 per cent of the total weight of seed cotton.” This may have been an upper estimate. By contrast, many published accounts noted that the new varieties yielded closer to 33 percent lint. ${ }^{29}$ This implies more than a 30 percent premium after ginning. Plantation records generally confirm the increase in lint yield but suggest a more complicated story of continual improvement. Mississippi planter Francis Terry Leak chose seeds with an eye on lint ratios. His records showed a gradual upward trend in lint turnout well after the first introduction of Mexican varieties. Between 1841 and 1846 he averaged 26 percent lint and by 1853-1857 he obtained a 30 percent yield. ${ }^{30}$ The Mexican cotton’s many

\footnotetext{
27 "Cotton," American Farmer (7 July 1820), p. 116. For other examples of the benefits of the new cotton see, "Free Produce Society," Genius of Universal Emancipation (30 October 1829), p. 58; H. B. Croom, "Some Account of the Agricultural Soil and Products of Middle Florida,” Farmers' Register (June 1834), p. 2; and Charles Jones, “On Cotton Culture," The Cultivator (June 1840), p. 98.

${ }^{28}$ Prominent secondary accounts reproduced these claims regarding the benefits of the Mexican hybrids. Claiborne, Mississippi, pp. 140-43; Watkins, King Cotton, p. 172; Gray, History, pp. 689-90; Moore, Agriculture, pp. 13-36, and "Cotton Breeding," p. 97. These writers all had a thorough understanding of cotton production technologies and Claiborne was a prominent antebellum planter.

${ }^{29}$ Gray, History, p. 703; Watkins, King Cotton, p. 172; H. B. Croom, “Some Account,” Farmers' Register (June 1834), p. 2.

${ }^{30}$ See, James Winchester of Cragforn, Tennessee to John R. Eaton of Granville, North Carolina, 9 December 1801, in the John Rust Eaton Papers, Coll. 234-z, SHC/UNC. The 1812 records of John Palfrey of Attakapas, Louisiana confirm a turnout of 0.25 pounds of lint for every pound of seed cotton in the early nineteenth century, Palfrey Family Papers, 1776-1918, Stampp, Records of Ante-bellum Southern Plantations [hereafter RASP], Ser. I, pt. 1, reel 1, p. 94. The records of William Reynolds of Barnwell report a turnout ratio of 0.30-0.32 in 1844, Reynolds Family Papers, SCL/USC. In 1847, Walter Wade of Jefferson County, Mississippi found a lint yield of "not quite 1/3 but more than 1/4," Walter Wade Plantation Diaries, 1834-1854, RASP, Ser. N, reel 18, p. 879. In the next year John Carmichael Jenkins, of the Natchez, Mississippi area, reported a ratio of 0.27, Elgin Plantation Journal \# 7, January 1848, p. 2 (typescript housed at the Historic Natchez Foundation). Francis Terry Leak Papers, 1839-1865, RASP, Ser. J, pt. 6, reel 24, pp. 407, and 531. As another indication that the jump in lint turnout was not a one time
} 
attributes led M. W. Phillips of Edwards, Mississippi to proclaim that the improved seed "can hardly be regarded as of less importance than the introduction of the gin stand." 31

The early success of Mexican cotton stimulated others to seek fresh introductions. In 1827 Timothy Flint noted that in Louisiana, Mexican cotton was "getting into common adoption, and the importation of seed from Tampico and Vera Cruz is becoming a considerable business.” ${ }^{32}$ This further increased the genetic material available to breeders. Cotton breeders had several competing objectives including higher yields; longer, finer, and stronger fibers; ease of picking; and resistance to pests. Early maturing cottons could be harvested before insects and diseases could multiply and destroy much of the crop, but such cottons generally had lower yields and fiber quality. The trick for breeders was to select crosses or mutations that combined the best qualities of different varieties. They did this by planting different varieties near to each other in experimental plots, by carefully selecting seed from plants that had desired qualities, and by isolating their premium cottons to prevent cross-pollination.

By the late 1820s two new Mexican hybrids, Petit Gulf and Alvarado, gained acclaim. Petit Gulf was developed by Dr. Rush Nutt of Rodney, Mississippi. The Nutt family began as local suppliers of superior cottonseed, but by the 1830s acquired a regional and even international reputation. ${ }^{33}$ Contemporary observers proclaimed that Petit Gulf was of higher quality than the first Mexican imports, its lint was less likely to fall to the ground if not picked promptly, and it ripened earlier. Petit Gulf widened the already considerable productivity gap separating the Mexican cottons from the Green Seed and Creole cottons.

affair, M. W. Philips (often Phillips) noted that his new Hogan seeds yielded 31 percent lint. This is "the largest yield I have ever found, and I have been thus testing all cotton for many years.” Turner, Cotton Planter's Manual, p. 106.

${ }^{31}$ Phillips, "Mexican Cotton Seed," p. 279. Variants of this comparison with the cotton gin were repeated by Affleck, "Early Days," pp. 668-69; Watkins, King Cotton, p. 13; Gray, History, p. 689; and Moore, Emergence, p. 28.

32 Timothy Flint, “Agriculture of Louisiana,” American Farmer (3 August 1827), p. 154.

${ }^{33}$ For orders for cottonseed, including one from India, from the Nutt plantations, see items NU 29, 49, 113, 221:18, 245, 271 in Papers of Rush and Haller Nutt, 1805-1933, Mss NU 1-365, Huntington Library, Art Collections and Botanical Gardens. The term "Alvarado" evidently applied to both cotton imported from the Veracruz region of Mexico and to crosses subsequently developed based on this parent. 


\section{The Diffusion of Mexican Cottons}

Plantation records as well as press accounts document the gradual spread of Mexican cottons throughout the Gulf region in the 1820s. In 1820 the American Farmer reported that Mexican cotton had recently been introduced to Louisiana and recommended that travelers to that state from other cotton growing regions "procure seeds and instructions for the culture of this ... very important cotton.” 34 We know that by 1824, John Garnier of the Santa Rosa Sound in the far western part of Florida was growing a mix of varieties including Mexican seed. ${ }^{35}$ The plantation records of James T. Magruder of Jefferson County, Mississippi first noted on 1 May 1824 that he was planting Mexican seed. In the same year, A. Penquite sought Mexican seed (as well as other types) from Rush Nutt. At the start of the 1825 planting season, the manager of John Quitman’s Port Gibson, Mississippi plantation was “very desirous to procure some Mexican Cotton seed.” Planters often experimented with Mexican for a few seasons before committing to the new seed. David Rees of Saint Martin's Parish, Louisiana may have tested Mexican cotton as early as 1822, but the first explicit mention appeared in May 1826 when he had planted Mexican seed in several fields. Rees's main concern was to find a variety resistant to rot. Rees was also growing Tennessee Green Seed and Creole. But in 1827 the American Farmer implied that Creole and Tennessee were still in use in Louisiana but losing favor. ${ }^{36}$ Clearly two decades after William Dunbar first received the Mexican seed, many planters in the lower Mississippi Valley were just beginning to adopt the new variety.

${ }^{34}$ Columbianus, “On the Cultivation, Management, and Employment of Cotton, No. 4,” American Farmer (7 July 1820), p. 116.

${ }^{35}$ In November 1824, Secretary of War John C. Calhoun sent samples of Garnier's cotton to John S. Skinner of the American Farmer. Skinner had Massachusetts cotton manufacturers appraise the samples and the Mexican cotton generally met with their approval. See Hemphill, Papers of John C. Calhoun, pp. 404-05, and J. C. Calhoun, “Florida Cotton,” American Farmer (4 February 1825), p. 362.

${ }^{36}$ James T. Magruder Cotton Book, 1818-1830, RASP, Ser. N, reel 12, p. 733; A. Penquite to Rush Nutt, 19 January 1824, item NU 271, Papers of Rush and Haller Nutt, 1805-1933, MssNU 1-365, Huntington Library, Art Collections and Botanical Gardens; Quitman Family Papers, 1784-1978, RASP, Ser. J, pt. 6, reel 5, p. 235; 1822 and 1826 plantation journals in Davis Rees Papers, 1803-1835, RASP, Series H, Reel 29, p. 807, and Reel 30, pp. 5, 9, 15. Timothy Flint, “Agriculture of Louisiana,” American Farmer (3 August 1827), p. 154. Furthermore, in the 1840s and 1850s when rot reappeared in the lower Mississippi Valley, some planters unsuccessfully experimented with the "old greenseed" imported from Tennessee in the hope that it might prove resistant. See several references in Elgin Plantation Journal \# 6, March through December 1847, and Walter Wade Plantation Diaries, 1834-1854, RASP, Ser. N, reel 18, p. 673. 
Previous accounts suggest that there was a lag of up to two decades between the spread of Mexican cottons (including hybrids such as Petit Gulf and Alvarado) in the West and their appearance in the Southeast. However, our examination of archival records reveals that many southeastern planters had begun experimenting with the new varieties by the 1820s. Ware reports that Mexican cotton first appeared in South Carolina in 1816 but offered no source, and we have not substantiated this early sighting. Archival accounts document that John Connors of Lancaster, South Carolina was growing Mexican cotton by 1825; Calvin Jones of Wake County, North Carolina and John Walker of King and Queen County, Virginia both reported the variety in 1827; as did Bryan Croom of Rocky Comfort, Florida by 1829. ${ }^{37}$ We know that Mexican cotton was still a novelty in Alabama in 1826 because David Moore, whose plantation was near Huntsville, caused “unusual excitement” when on 28 and 29 August his 27 hands picked "the enormous quantity of 8921 pounds of seed cotton, being an average of 330 to the hand for two days. . . . It was Mexican cotton, which bears very large bolls, and was beautifully opened.”38 Retrospective accounts indicate that many others were experimenting with Mexican cotton in the 1820s. As an example, James Davis of the Fairfield District, South Carolina noted that between 1825 and 1827 he "substituted what is called the Mexican cotton in the place of the green seed.” By 1835 he was unable "to find a single plant of the green seed kind growing the neighborhood" to test its performance against Petit Gulf, the then-dominant Mexican hybrid in his region. ${ }^{39}$ Davis appears to have been totally committed to Mexican soon after his first experiments, but most planters continued to grow other varieties for years. There are several explanations for this coexistence. In some settings the Mexican cottons either were not overwhelmingly better or still needed to be acclimated. Farmers may have been playing it safe. Growing different varieties could also help spread out the planting and harvest seasons. In addition, many

\footnotetext{
${ }^{37}$ Ware, “Origin,” p. 13; John Connors Papers, SCL/USC, 28 April 1825; Calvin Jones noted in his farm journal that the Mexican cotton "hangs out of the boles (sic) to the ground," Calvin Jones Papers, 1785-1929, RASP, Ser. J, pt. 8, reel 4, frame 0708; John Walker Papers, 1824-1844, RASP, Ser. J, pt. 9, reel 32, p. 996 and various entries on reels 32-33. Letter from Byran Croom to Hardy B. Croom, 25 July 1829, in the H. B. Croom Papers, Coll. 3372, SHC/UNC.

${ }^{38}$ American Mercury (10 October 1826), p. 2.

${ }^{39}$ James Davis, “On the Different Kinds of Cotton," Farmer \& Gardener, and Live-Stock Breeder and Manager (22 December 1835), p. 271.
} 
farmers were unwilling to pay for large quantities of commercial seed, and it could take years to produce sufficient planting seed for an entire plantation. ${ }^{40}$

The diffusion of the new Mexican hybrids outside the Mississippi Valley was also much earlier than many presumed. South Carolinians John Connors and William Richardson both planted Alvarado in 1829, as did John Lawton in 1833, and James Calhoun in 1834. In 1834, William Proctor Gould of Greene County, Alabama was planting Petit Gulf as well as Mexican. In addition, he gave a neighbor, Dr. Means, both types of seed. In 1836 Carolina planter Walter Peyre grew Alvarado, Petit Gulf, and both Green Seed and Black Seed varieties. ${ }^{41}$ Others in the southeast had already adopted Petit Gulf, at times with enthusiasm. For example, James Henry Hammond of South Carolina noted in 1833, "planted some Petit Gulf cotton and well pleased with it.” In 1834 he observed, “planted half my crop in Petit Gulf. . . . Shale [sic] plant all Petit gulf hereafter." ${ }^{42}$

Several forces facilitated the diffusion of the new cotton varieties. The praise for the new seeds in agricultural journals and newspapers helped spread the word. In addition, a regional market in cotton seeds emerged. Here again the press played an important role by providing a medium for both sellers and buyers to advertise. As early as 1770, advertisements for cotton seed appeared in the Georgia Gazette of Savannah. In 1798 another Savannah paper noted that William Belcher was offering "Sea Island, White Nankeen, and the common green Seed, of the upper country." ${ }^{43}$ By the spring of 1833, dealers were advertising Mexican seed in Alabama, and by 1835 there was an explosion of ads in the southeastern press for “Alverado” and Petit Gulf. ${ }^{44}$

\footnotetext{
${ }^{40}$ As one of many examples, John Walker noted in 1834 that he was experimenting with one-half gallon of “blackseed” cotton, John Walker Papers, 1824-1844, RASP, Ser. J, pt. 9, reel 33, p. 109.

${ }^{41} 25$ April 1829 entry in John Connors Papers, SCL/USC; 24 September, 1 October, and 5 December 1829 entries, William Guignard Richardson Papers, SCL/USC; Thomas Walter Peyre Plantation Journal, 1812-1851, RASP, Ser. B, reel 5, pp. 90, 98, 114; Alexander Robert Lawton Papers, 1774-1897, RASP, Ser. J, pt. 3, reel 26, p. 737; James Edward Calhoun Plantation Journal, 1830-1834, in John Ewing Colhoun Papers, 1774-1961, RASP, Ser. J, pt. 3, reel 29, pp. 512-29. William Proctor Gould Diary, 1828-1856, M-1192, pp. 20-21, SHC-UNC.

${ }_{42}$ Papers of James Henry Hammond, 1795-1865, RASP, Ser. A, pt. 1, reel 14, p. 67.

${ }^{43}$ Georgia Gazette (25 April 1770), p. 4; Columbian Museum (27 March 1798), p. 1.

${ }^{44}$ For several examples of early ads for Petit Gulf and Alvarado seed, see Alabama State Intelligencer (2 March 1833), p. 3 and (25 July 1835), p. 4; Southern Patriot (20 January 1835), p. 3, (27 January 1835), p. 3, (30 January
} 
In the vernacular of the day, the older varieties tended to "run down." This could be for a number of reasons-what passed for Petit Gulf might have been accidently crossed with inferior cottons, it could have become more susceptible to diseases, and the like. Although advertisements found in southern farm journals and plantation records show Petit Gulf remained popular throughout the antebellum era, a large number of new varieties came on the market in the 1840s and 1850s. Some represented improvements for specific locales, others were disappointments. ${ }^{45}$ Among the most popular was One Hundred Seed, which was bred and distributed by Col. Henry W. Vick of Vicksburg, Mississippi in the mid-1840s. ${ }^{46}$ In 1839 Vick began the annual process of having his most able slaves make special pickings in which they harvested only the finest bolls from the largest and most prolific plants. This cotton was ginned separately and then grown in isolated fields. Vick often ventured into the fields himself in search of valuable mutations and crosses. He personally selected the progenitor of the One Hundred Seed cultivar in 1843 from the particularly appealing bolls of a single plant he discovered while visiting another plantation in the Delta. ${ }^{47}$ He then increased this seed for a few years before marketing it. Most planters typically bought small quantities of commercial seed which they then tested and increased themselves. They had to be very careful to maintain seed quality given the potential for cross-pollination in the fields and seed mixing at the gin. Specialized seed producers such as Vick were particularly diligent to separate their test fields and to clean their gins between runs. ${ }^{48}$

Other important varieties produced by antebellum Mississippi Valley breeders were Sugar Loaf (1843), Mastodon (before 1846), Boyd's Prolific (before 1847), and Banana (before 1848). Sugar Loaf was first in the line of cluster types (that is, the plant tended to have multiple bolls at each node on its short fruiting limbs, making the bolls cluster together). Boyd's Prolific was the pioneer variety in the

1835), p. 3, (2 February 1835), p. 3, (3 February 1835), p. 3, (3 March 1835), p. 3, and (19 March 1935), p. 3; and Macon Weekly Telegraph (26 February 1835), p. 4.

${ }^{45}$ Smith, Crop Production, p. 297; Ware, “Origin,” pp. 12-14.

${ }^{46}$ Moore, "Cotton Breeding," pp. 95-104, and Emergence, pp. 12-16. From reading Moore, one might surmise that a rot disease wiped out the Green Seed varieties. To the contrary, in 1880 Tennessee farmers reported that Green Seed varieties were widely grown in the state. Hilgard, Report, p. 99.

${ }^{47}$ Moore, “Cotton Breeding,” pp. 99-101; Vicksburg Sentinel (7 July 1847), p. 1.

${ }^{48}$ Moore, Emergence, p. 13; Ware, “Origin,” pp. 12-14; Smith, Crop Production, p. 297. 
semi-cluster line (which possessed the clustering habit in a less pronounced form). Varieties such as Mastodon were highly popular in certain regions but were considered "humbugs” in others. ${ }^{49}$

In 1868 Joseph Lyman reflected on the dynamics of the seed industry : "Beginning with the year 1820, and from that time forward, various planters in different parts of the cotton growing States have devoted themselves to the development and sale of improved varieties of cotton seed, and certain styles of cotton have for two, three, or four years, enjoyed a great, though ephemeral popularity, and, then, as suddenly, been pushed aside for a new reigning favorite. The improvement of a cotton seed as a business, and sale of the improved varieties, has enabled quite a number of prominent and enterprising planters throughout the South to realize handsome fortunes." ${ }^{50}$ Cotton improvement was not the monopoly of a few well-known breeders. Our reading of plantation diaries suggests that most planters large and small typically grew more than one variety in a given year, carefully observing the many pros and cons of each. Planters such as John Carmichael Jenkins, Francis Leak, and Charles Whitmore regularly grew three or more varieties and were testing others in garden plots. ${ }^{51}$ Antebellum observers were impressed and at times astounded at the high prices the new seeds brought in the market. Ordinary cotton seed might sell for 25 cents per bushel (when used for manure) and was often simply discarded. By contrast, Petit Gulf seed regularly fetched twice as much. Seeds of choice varieties such as Sugar Loaf, Brown, Hundred Seed, Banana, Multibolus, and Prolific, “under ordinary circumstances, command from one to three dollars per bushel.” And when first introduced, Mastodon seed netted five dollars a bushel, Banana “at first sold for a hundred dollars a bushel [and] some paid ten cents apiece [again roughly $\$ 100$ per bushel] for 'Hogan' seeds.”,52

\footnotetext{
${ }^{49}$ Watkins, King Cotton, pp. 173, 195, 217, 243.

${ }^{50}$ Lyman, Cotton Culture, p. 121.

${ }^{51}$ Charles Whitmore Plantation Journal, Coll. 2406, SHC/UNC. As an example of the care devoted to selecting cotton, Mississippi planter Everard Green Baker includes instructions in his diary to "label each kind accurately" regarding "length of lint," "quality \& quantity," and "easiness to pick" when taking samples from the stalk. 1861 diary transcript, p. 4, in the EverardGreen Baker Papers, Coll. 41, SHC/UNC.

${ }^{52}$ Lyman, Cotton Culture, pp. 121, 125. Also see Moore, “Cotton Breeding,” pp. 100-02.
} 
New varieties gained considerable attention in the southern and even the northern press. As an example, in 1854 Harper's Magazine reported that "whenever, by good fortune, a higher-yielding cotton plant appears 'instantly ... the local newspapers teem with advertisements and commission houses are filled with the magic seed [for marketing]." ${ }^{53}$ Improved cottons of both the Sea Island (from Seabrook) and Upland (Petit Gulf and extra-prolific) varieties were included in the Great Exhibition when it opened in New York in 1853. The writer for the Times observed that "although the Crystal Palace contains many articles which make more show, and will attract more attention, it has none which have exercised a greater influence upon the civilization of world,” than these cottons. ${ }^{54}$

In the late antebellum period, some of the seed producers who had started as planters, such as Martin W. Philips, conducted ambitious privately-funded agricultural experiments and disseminated their findings and latest creations for free. In time, Philips was “drawn into a profitable seed business selling name brands from his Mississippi plantation.”55 Other seedsmen, such as David Dickson of Hancock County, Georgia, were commercial operators from the beginning. Much like those of northern manufacturers of agricultural machinery, Dickson's advertisements in the 1850s (such as Figure 2) featured testimonials from satisfied local customers. ${ }^{56}$ The new seeds were not protected by patents, yet the innovations continued to flow. The speed of innovation appears to have been more rapid in the Upland cotton sector, where an ethos of greater openness prevailed, than in the Sea Island sector where planters closely guarded their improved seeds and cultural practices as trade secrets.

\section{The Picking Revolution}

Advances in the efficiency of cotton picking are of special interest. On most cotton plantations, picking represented the largest single use of labor. During the year, slaves on cotton plantations worked

\footnotetext{
53 Thorpe, “Cotton and Its Cultivation,” p. 449.

${ }^{54}$ New York Times (26 July 1853), p. 1.

55 Norse, "Southern Cultivator," pp. 245-46.

${ }^{56}$ David Dickson Advertisement for Boyd's Extra Prolific, 1854, Hargrett Library Broadside Collection, 1850-1859, Mss. 2622, Hargrett Rare Book \& Manuscript Library, University of Georgia Libraries.
} 
on many tasks, but the non-cotton activities were chiefly inputs into the production of the cotton cash crop. Jobs such as raising corn and peas, tending animals, and clearing new land were, when possible, scheduled to fill down times in the year-long cotton cycle. Although the cotton cycle varied with location and weather, in general, preparing the land by clearing dead stalks started in January, plowing and working to control weeds began soon thereafter, and planting and chopping accelerated the work pace beginning in April. Depending on latitude and other factors, the picking season stretched from late August into December and in some seasons even later. The rate of picking tended to peak in October and early November when more cotton was open. Picking required dexterity and diligence. It involved stoop labor to gather the low-lying bolls and repetitive motions of the hand amidst the plant's thorny burrs. But it did not require great physical strength, which contributed to the high rate of participation of the slave population, including children and the elderly, during the picking season.

Picking was the key binding constraint on cotton production. Capturing a sentiment often noted in antebellum accounts, Gallman asserted that "a field hand could raise very much more cotton than he could pick” and the plantation's “capacity to pick ... governed the volume of land put to cotton.”57 However, most estimates of labor requirements fail to appreciate that this constraint was not fixed over time. As a rough approximation, in the early period, an individual slave could pick only one-half of the acreage of cotton that he/she could plant and cultivate. With improvements in picking rates, this ratio increased, allowing planters to expand cotton acreage and more evenly employ labor in higher value tasks. $^{58}$

One sign of the importance of the harvest operations is that many slave masters kept extensive logs detailing the daily picking output of individual slaves. Absentee owners often required their overseers to keep such records so that the owners could better assess day-to-day farm activities, but many

\footnotetext{
${ }^{57}$ Gallman, "Self-Sufficiency,” p. 23, also 19-23. Also see Phillips, American Negro Slavery, p. 207; Anderson and Gallman, "Slaves as Fixed Capital," p. 36; and Wright, Political Economy, pp. 57-60.

${ }^{58}$ Mendenhall, "History of Agriculture in South Carolina," p. 119, notes that in the early 1820s laborers could pick only $1 / 2$ to $3 / 4$ of the acreage they could plant and cultivate, but, p. 189, that the introduction of Mexican cottons "practically eliminated" this imbalance.
} 
resident owners also caught the recordkeeping bug. ${ }^{59}$ The data allowed for comparisons with past years, and helped set expectations for tasking the pickers. These records were precursors to the time-in-motion studies initiated by Frederick Taylor and the "Scientific Management" movement in the early twentieth century. $^{60}$

Failing to meet picking standards had severe consequences. In 1834, S. A. Townes of Marion, Alabama threatened to "make those bitches go at least 100 [pounds] or whip them like the devil."61 In the 1830s, Dr. J. W. Monett of Mississippi asserted that after weighing an individual's daily picking, masters would whip slaves for light or trashy picking. ${ }^{62}$ On several occasions, Louisiana planter Bennet Barrow ordered a whipping for all hands because the output was too low. As yet another example, John Edwin Fripp of South Carolina recorded “popping” and “switching” his slaves for light picking. On the Mississippi plantation of John Quitman and Henry Turner, a number of enslaved African-Americans ran away rather than face punishment for light or trashy picking. ${ }^{63}$

\footnotetext{
${ }^{59}$ Absentee owners also desired the records to evaluate their overseers and to prevent shirking, malfeasance, and so on. This motivation is suggested in the following passage in a 4 May 1834 letter from President Andrew Jackson in Washington to his son, Andrew Jackson, Jr., back in Tennessee: "My son, when you left me we had a right to believe our cotton crop would have yielded at least fifty thousand pounds baled cotton; we had a right from information to believe we would have 180 thousand in the seed, to 200. Now it appears that there was not raised more than about 114 to 120 thousand in the seed. I name this, that this fall you may guard against such imposition, and have a cotton Book on which must be entered the daily picking of each hand, and make the overseer responsible for the accuracy of the cotton Book.” Bassett, Correspondence of Andrew Jackson, pp. 263-64. Affleck's Southern Rural Almanac 1854, p.15, opined that it was “preposterous" to place an enterprise worth $\$ 50,000$ to $\$ 200,000$ in the hands of an overseer who was unable or unwilling to keep accurate records.

${ }^{60}$ Fogel, Without Consent, p. 27; Metzer, “Rational Management,” pp. 123-50.

${ }^{61}$ Townes to George Franklin Townes of Greenville, South Carolina, 18 September 1834, in Townes Family Papers, SCL/USC.

${ }^{62}$ In an appendix of Ingraham, Southwest, pp. 281-94, J. W. Monett wrote: "After the weighing is over, and the baskets are emptied, or turned bottom upward, upon the scaffolds, the overseer takes the slate, and examines the weights attached to each name. Those who are found to have brought in less than their usual quantity, unless for good reasons, are called in the order of their names; the individual advances, and if his reasons are insufficient, he is ordered to lie down upon his face, with his back exposed; when he receives ten, twenty, or fifty stripes with the whip, according to his deserts. In this way the overseer goes over the list, punishing only those who have idled away their time. ... No one knows that he is to be punished until his name is called, when he has an opportunity of giving his reasons for his imperfect day's work."

${ }^{63}$ Davis, Plantation Life, p. 162; on 19 October 1858, Fripp wrote: "gave nearly all of them a poping [sic] as they do not go over more than a task a day - they should go over more ground or bring more cotton,” John Edwin Fripp Papers, 1817-1905, RASP, Ser. J, pt. 3, reel 25, p. 712; Quitman family papers, 1784-1978, Ser. J, Pt. 6, reel 6, pp. 889, 891, 895.
} 


\section{A New Cotton Picking Dataset}

Plantation managers recorded picking data in various documents including plantation journals, diaries, cotton books, ledgers, letters, and the like. Over time recordkeeping became more formalized with many planters employing bound account books with printed templates designed especially for this purpose. Such preprinted records, which appeared by the 1810s, undermine any romantic notion of a sleepy plantation system run by pre-capitalist masters. The most popular cotton account book was produced by Thomas Affleck, a noted nurseryman, experimenter, and farm journalist. The first edition of the Affleck Plantation Journal and Account Book appeared in 1847. Within a few years he offered three different volumes—one for small plantations with up to 40 slaves, one for mid-size plantations with 80 hands or less, and one for plantations with up to 120 hands. ${ }^{64}$ In addition to the pages efficiently laid out for recording picking, the Affleck (and competing) books provided forms for listing the slaves' names, ages, and values, births and deaths, stock and equipment inventories, the weight of individual cotton bales, and other valuable information. The volumes also contained space for a diary. The daily entries (and marginal notes found with the picking records) often give a detailed sense of the pulse of plantation life, including information on work assignments, plant varieties, crop damage due to insect and disease infestations and bad weather, owner-overseer relations, cotton sales and quality, days lost to rain, and whether or not the slaves worked a full or half day, whether the slaves worked on Saturdays and Sundays, and the like. Of course the overseers and owners differed significantly in their attention to detail, but in many instances we were able to supplement the information found in the picking records with commentary extracted from diaries, letters, and other types of farm journals. Figure 3 shows an example of two unusually legible and reasonably complete pages from an Affleck book. These two pages capture

\footnotetext{
${ }^{64}$ Williams, “Thomas Affleck,” pp. 40-48. In 1860 Affleck published a fourth book for plantations with more than 120 slaves, p. 46. Given Affleck's practice of employing several different printers, it is difficult to determine the total number of books issued. In letters to B. H. Norman (1 January 1851) and to Robert Sears (9 January 1851), Affleck anticipated a combined market of 5,000 copies per annum for his cotton and sugar account books. Letterbook 5-90, Thomas Affleck Papers, Special and Archival Collections, Texas A\&M University.
} 
the activities for the week of 22 October 1860 on the Eustatia Plantation in Mississippi detailing the picking output of 54 slaves with about 260 individual picking entries. ${ }^{65}$

Our dataset captures 704,800 individual picking entries from 142 separate plantations over a total of 509 plantation-crop years spanning the period from 1801 to 1862. 474 of the crop years are from Upland cotton operations and 35 are from Sea Island operations. ${ }^{66}$ The quantity and quality of the data differ greatly from plantation to plantation. For 52 plantations we have data for just one, or only part of one, picking season. At the other extreme we have data for 22 years for the Leak plantation located in Tippah (now Benton) County, Mississippi. The Leak plantation sets the record for the most entries for a single plantation at 79,602. To expand coverage for our investigation of changes in picking rates, we also mined plantation records containing aggregate daily picking totals and the numbers of pickers. There are 40 plantation years in our sample for which we have only aggregate data. ${ }^{67}$

We scoured public archives and private collections across the United States for plantation records. The resulting sample is not distributed uniformly with cotton production over space or time. Figure 4 displays the geographical distribution of our sample. The Old South region accounts for 103 of our 474 Upland plantation year observations, with coverage extending from 1801 to 1862 . The New South makes up 371 Upland observations, beginning in $1805 .{ }^{68}$ Mississippi with 200 crop year observations and Louisiana with 72 are especially well represented and coverage for this region extends

\footnotetext{
${ }^{65}$ Eustatia Plantation, Mississippi, Account Book 1861, Ohio Historical Center Archives. This plantation book is featured on the PBS "Slavery and the Making of America” Web site.

${ }^{66}$ Sea Island cotton operations include 12 plantations and roughly 24,000 daily observations. For the James Guignard plantation of Edisto, South Carolina we separate its Sea Island and Green Seed cotton operations. Guignard Family Papers, SCL/USC. One of the Upland operations, the farm of German emigrant J. F. Leyendecker of Colorado County, Texas may include only free workers. Leyendecker Family Papers, 1817-1987, The Center for American History, University of Texas at Austin.

${ }^{67}$ As an example, over the 1840s, the records for James Henry Hammond's plantation include a type of workbook (pre-dating the Affleck publication) recording the number of workers performing each task or operation including picking cotton, another set of accounts recording the total weight of cotton picked from each field each day, and a third set of records tabulate total output by field. By combing these accounts we can derive a well-documented estimate of the aggregate picking efficiency of the slaves on the Silver Bluff plantation. Such data are not as rich as the individual-level records, but they are sufficiently informative to warrant inclusion in the plantation-level analysis.

${ }^{68}$ We follow the convention of defining the Old South as including the members of the original 13 colonies (Georgia, North Carolina, South Carolina, and Virginia) and the New South as those states entering the Union after Independence (Alabama, Arkansas, Florida, Louisiana, Mississippi, Tennessee, and Texas).
} 
back to 1805. In general, the data become more abundant over time. Over all states, we have data for 31 plantation years before 1820; 24 for the decade of the 1820s; 47 for the 1830s; 122 for the 1840s; 214 for the 1850s; and 71 for the early 1860s.

\section{Changes in Picking Efficiency}

Figure 5 documents the changes in daily picking rates on cotton plantations between 1801 and 1862. Panel A displays mean daily picking rates on a log scale for Upland cotton operations; Panel B does the same for Sea Island cotton operations. Each data point represents the mean amount of cotton picked per day for a plantation crop year. Thus a plantation with 300 entries covering only part of the picking season has equal weight as a plantation with 5,000 entries spread across the entire season. The labels on the observations indicate their locations by state (MS=Mississippi, LA=Louisiana, and so on) or their type (SI=Sea Island).

Table 2 reports regressions of the log of the mean picking rates on the linear and quadratic time trends. ${ }^{69}$ The results are displayed in Figure 5 as the solid trend line. By these estimates, the mean pounds picked increased over 2.3 percent per annum, rising from 28.1 pounds in 1801 to 114.2 pounds in 1862. This represented an increase of 4.1 times. Our sample provides a better sense of the timing of the transition, with the quadratic term indicating that the rise in picking rates was slowing down by the 1850s. In the additional regressions, we also control for size of the picking labor force, gender composition, seasonality of activity, and region, Old vs. New South. ${ }^{70}$ Including these controls reduces the size of the sample by 78 observations. Evaluating equation (3) for Upland cotton operations at the sample means of these controls indicates that adjusted picking rates more than tripled (3.19 times) between 1801 to 1862,

\footnotetext{
${ }^{69}$ Substituting the median for the mean does not significantly alter the results.

${ }^{70}$ Controlling for the age distribution of the labor force is difficult at the plantation level. In our future empirical analysis of the individual-level picking data, we intend to include both gender and age controls. Such an analysis should help separate the direct effects of gender on picking rates from indirect effects arising from the correlation of labor force composition with other productivity-related attributes of the plantations that is suggested in the fixedeffect regression results reported in Table 3. Non-peak activity is measured by picking in months other than September, October, and November.
} 
growing at a rate of 1.90 percent per annum. Note this calculation does not allow for regional shifts in production; the coefficient on New South location in equation (3) indicates picking rates per day were almost 57 percent (that is, exp[0.451]) higher in the New South than in the Old South.

The picking rates do display increasing variation over time. The standard errors reported in Table 2 use the White robustness correction and the picking rates have already been transformed into logs (percentage terms). But rather than viewing the heterogeneity as merely a statistical problem, we believe that the high and increasing variance in plantation mean picking rates is an important phenomenon calling for further investigation and interpretation. Focusing on the 1850s and early 1860s, the coefficient of variation (the ratio of the standard deviation to the overall mean) of the average picking rates on Upland operations was 0.404 . Thus, on late antebellum era plantations, there was a one-standard-deviation spread of roughly 40 percent in the average productivity per worker performing the key task in producing a relatively standardized commodity trading in world markets. Yet as wide as the variation was in the 1850s and early 1860s, all but one or two percent of the operations in that period had higher picking rates than the median operation in the period before 1820; indeed, the breakpoint for the bottom 25 percent in the later period was above the highest operation in the earlier period.

\section{Why Did Picking Rates Increase?}

To explain the increase in picking rates we explore four hypotheses. First we ask if the increase in economies of scale associated with the more efficient use of the gang system accounted for the upswing in picking efficiency. We then look at a related issue by asking if planters learned to be more efficient managers. Although both of these hypotheses play a prominent role in the cliometrics story of crosssectional efficiency differences, neither attracted much contemporary notice and neither appears to explain much of the increase in picking efficiency in our sample. We next explore the impact of the movement of cotton production onto superior western lands. We follow this discussion with an analysis of the biological revolution in cotton varieties and the breeding activities that reshaped the antebellum economy. 
Scale and Gangs:

Fogel and Engerman have argued that slave plantations had a significant efficiency advantage because of their ability to exploit the "gang system.” According to this view, the gang system was an innovation akin to the moving assembly line of the early twentieth century. Slaves "who toiled in the gangs of the intermediate and large plantations were on average over 70 per cent more productive than either free farmers [northern and southern] or slaves on small plantations.” Fogel asserts that under the gang system slaves worked more intensely but for fewer hours than free workers. The "greater intensity of labor per hour, rather than more hours of labor per day or more days of labor per year, is the reason the index of total factor productivity is 39 percent higher for the gang-system plantations than for free farms."71

One might expect that such significant productivity enhancing innovation would have been widely discussed at the time—certainly Henry Ford's assembly line did not go unnoticed. ${ }^{72}$ In fact, the use of the term gang was rare in discussions of picking operations in the hundreds of cotton books and plantation journals that we reviewed, usually occurring with reference to a trash, house, or children's gang performing some unusual activity. More generally, we have seen almost no slave era testimony extolling the productivity advantages of the gang system (under any name) in any cotton production activity. Nevertheless, was the gang system somehow responsible for the growth in picking efficiency? This is

\footnotetext{
${ }^{71}$ Fogel, Slavery Debates, pp. 28-39. Fogel argues that small slaveholders (those with 1-15 slaves) could not effectively capture the benefits of the gang system, so plantations with more than 15 slaves account for nearly all of the productivity advantage. Large plantations were only slightly more efficient than intermediate size units. The gang system propelled slaves to work with less wasted motion, with an "unremitting, machine-like quality." "It was the gang system that forced men to work at the pace of an assembly line (called the gang) that made slave laborers more efficient than free laborers.” Fogel, Without Consent, pp. 78-79. The work schedule was the result of a conscious decision by slave owners. Long rest periods during the day and time off on the Sundays were not "boons that slaveholders granted to their chattel but ... conditions for achieving the desired level of intensity." Fogel, Slavery Debates, p. 33.

${ }^{72}$ Based on his careful review of the accounts of Mississippi plantations, Moore, Emergence, pp. 77-84, 95-96, suggests that the traditional gang labor system was passing out of use in the 1840s. Philip Morgan has further argued that U. B. Phillips' claim that the gang labor system was employed on virtually all short staple cotton plantations oversimplifies matters. Morgan, “Task and Gang Systems,” pp. 189-90, 197-98, 206-07. See also Wright, Slavery, pp. 95-96.
} 
very unlikely because by all accounts, including those of Fogel and Engerman, cotton picking was not a gang activity. Picking was performed on an individual basis conceivably because of the widely different skill levels of the pickers and the ability to easily monitor and measure output. ${ }^{73}$ But perhaps larger crews were more efficient picking forces.

To test for the effects of scale economies we introduce controls in specifications (2) and (3) of Table 2 for plantation size as measured by the average number of pickers working per day. Plantations with larger picking crews tended to have higher rates of picking per person (which is consistent with economies of scale, positive correlations between size and managerial efficiency, and other explanations). ${ }^{74}$ The measured effect of (the log of the) size of the average number of pickers as shown in specification (2) for the Upland cotton operations appears quite large at 0.196 . This would imply that doubling the size of the crew would lead to a roughly 20 percent increase in daily output per picker. Controlling for crew size reduces somewhat the estimated time effects, with the adjusted daily picking rates increasing by 1.92 percent per annum. ${ }^{75}$ But including controls for seasonality, gender, and location as shown in specification (3) of Table 2 for the Upland cotton operations measurably reduces the picking crew coefficient. ${ }^{76}$

Wright and others have long argued that a plantation's size was correlated with its management structure, location (climate and soil type), and other productivity-related attributes, which makes

\footnotetext{
${ }^{73}$ Fogel and Engerman, Time on the Cross, p. 206, observed that "harvest operations do not appear to have offered the opportunities of division and specialization that existed during the planting and cultivation seasons. ... In the absence of an interdependence that could be exploited to promote an intense rhythm of work, planters attempted to achieve the same objective by dividing harvest hands into competing groups. There were daily as well as weekly races, with prizes (bonuses) offered to the winning team and to the leading individual picker. There were daily weigh-ins of the cotton picked, and those who did not respond to the positive incentive had to face the abuse, verbal or physical, of the driver, if they fell too far below the expected pace.” Our reading of a large number of plantation records suggests that contests were far less common than the literature portrays. Moreover, contests continued into the post-bellum era. As an example, the Hammond plantation records report a picking contest in September 1873, Papers of John Henry Hammond, 1795-1865, RASP, Ser. A, pt. 1, reel, 1, p. 798.

${ }_{74}^{74}$ Wright, Political Economy, passim, “Efficiency of Slavery,” pp. 219-26, and Slavery, pp. 94-112.

${ }^{75}$ Our "test" of the scale hypothesis does not directly confront the essence of Fogel and Engerman's hypothesis. They claimed that the effect of scale was discontinuous - plantations with more than about 15 field hands were more efficient than those with fewer hands. The vast majority of plantations in our sample had more than 15 field hands. ${ }^{76}$ This change is not an artifact of the downsized sample in specification (3); using the same sample with specification (2) results in a coefficient on the Log(Pickers) variable of 0.193, (robust s.e. 0.028).
} 
disentangling the separate effects difficult using cross-sectional data. Our panel data allow us to address this issue. Table 3 presents results on the determinants of daily picking rates controlling for plantation fixed effects. (This requires dropping 46 Upland cotton operations for which only one year of data is available.) Adding these controls eliminates the crew-size effect. ${ }^{77}$ It also diminishes the coefficient on gender, suggesting that the fraction of pickers who were male was correlated with other unmeasured productivity-related attributes of the plantations. The time effects remain strong, consistent with a 1.87 percent increase per year in picking rates even while holding location constant. Consistent with Wright's hypothesis, plantation characteristics such as location and soil quality clearly had a strong effect on picking productivity.

\section{More Efficient Exploiters:}

To control for the possibility that picking rates increased because slave owners learned over time to exploit larger picking crews more efficiently, we also included a term interacting the year and log of the picking crew size. Its coefficient had a statistically insignificant effect (at the 10 percent level) and its inclusion provided no additional explanatory power. If planters were becoming better managers (or just more callous and more demanding, i.e. better slave drivers) this increased "skill” should have allowed them to utilize their slaves more effectively in other activities besides picking Upland cotton. We can test this managerial hypothesis by looking at a closely related activity—-the production of Sea Island cotton. As Panel B of Figure 5 indicates and specifications (1) and (3) for Sea Island operations in Table 2 show, picking rates for this type of cotton changed little over the antebellum period. This is precisely what one would expect from reading contemporary accounts. While there was considerable testimony proclaiming the wonders of new Upland varieties, there was no parallel trumpeting of the productivity virtues of new

\footnotetext{
${ }^{77}$ This change again is not an artifact of changing the sample. Running specification (2) without fixed effects on the sample of Upland operations with multiple observations yields a coefficient on the Log(Pickers) variable of 0.186, (robust s.e. 0.030).
} 
Sea Island varieties. Our conclusion at this juncture is that managerial innovations (our first two hypotheses) unlikely accounted for much of the increase in picking efficiency.

The Shift in Output to Better Lands:

The territorial expansion of the cotton-slave frontier was one of the most controversial issues of the antebellum era, with claims and counterclaims regarding the importance of new lands in preserving the political and economic power of the slave South. Much of this literature lies at the foundation of the early debates over the profitability of the slave system. ${ }^{78}$ For all the discussion of the political and economic implications of the spread of slavery, there has been no precise measure of the actual spread of cotton culture and little understanding of how technological forces help explain the pattern of settlement of the cotton South. We offer a fresh perspective on the geographical movement of cotton production. In the early 1790s, U.S. production was concentrated along the coast of Georgia and South Carolina. By 1839 the geographic center (median) of the production of Upland cotton was near Greensboro in west central Alabama, and by 1859 the center was just west of the Mississippi-Alabama border. To provide perspective, it was not until the 1880s that the median geographic center of wheat production shifted west of this longitude. The speed of cotton's westward movement before the Civil War is all the more impressive when one realizes that over the entire period from 1860 to 1920, the geographic center of cotton production remained within the boundaries of the state of Mississippi. ${ }^{79}$ Figure 6, which plots annual state-level commercial cotton production between 1800 and 1860, offers another perspective on the enormous regional shift in cotton production. ${ }^{80}$ The shift away from the Old South began in earnest in the early 1810s. By 1833 its share had fallen from over 95 percent of total output to less than one-half and

\footnotetext{
${ }^{78}$ Phillips, American Negro Slavery, pp. 169-86, 332-37; Ramsdell, “Natural Limits,” pp. 151-71; Passell and Wright, "Efficiency," pp. 1188-1202; and Lee, Westward Movement. The same forces that contributed to the western movement of slavery also help explain the movement of slaves from urban to agricultural employment. Our analysis adds to Goldin's, Urban Slavery, emphasis on "pull” factors in explaining the decline in urban slavery.

${ }^{79}$ Olmstead and Rhode, Creating Abundance, chapter 13.

${ }^{80}$ Watkins, King Cotton, passim.
} 
by 1859 to less than one-quarter. In fact the westward shift was even more pronounced than the aggregate state-level data reveal because Georgia’s production shifted markedly to the interior.

The effects of the westward shift in production and the increase in picking rates were closely intertwined. Figure 7 and Table 4 address this issue by decomposing our picking sample into the Old and New South. Focusing on specification (1) in Table 4 and on the period when data exist for both regions, we observe that estimated picking rates in the Old South increased from 38.7 pounds per day in 1811 to 84.4 pounds by 1862. This represented an increase of 1.52 percent per annum. Estimated picking rates in the New South in 1811 were 42.3 pounds per day, about 9 percent higher than in the Old South at that year (and likely within error bounds of the estimate). But picking rates grew much more rapidly in the New South, reaching an estimated 125.4 pounds in 1862. This was 49 percent higher than in the Old South the same year. It was three times higher—consistent with a growth rate of 2.13 percent per annum — than in the New South in 1811. Note that growth in the Old South was roughly linear in time (the quadratic coefficient is small) whereas growth in the New South was rapid in the 1820s and 1830s and then slowed. As a result, the gap between picking rates in 1840 was huge- the average picker of the New South gathered 110.7 pounds per day whereas his or her counterpart in the Old South collected only 61.3 pounds. (This calculation does not control for picker characteristics.)

Table 5 reports the results controlling for plantation fixed effects for the Old and New South samples. The regional differences in the growth rates become smaller with these controls. The reported levels, reflecting differences in both observable and unobservable variables, remain significantly higher for the New South plantations than for the Old South plantations.

The dynamics of southern development were a function of the interaction of biological innovations and western movement. The existing view emphasizes that the West enjoyed a productivity advantage because the land in its vast alluvial basins was inherently better than the land common in the East. Moreover, the virgin land in the West had not yet been mined of its nutrients as had purportedly occurred in the East. However, these long-standing explanations of East-West productivity differences tell only part of the story because the rapid westward movement in cotton production in the years before 1833 
occurred precisely when western cotton producers enjoyed their greatest varietal advantage over eastern producers. Most of the new cotton varieties were invented in the West, and they were undoubtedly best suited for the area where they first evolved thereby enhancing the West's comparative advantage. The new varieties gradually were adapted to displace older varieties in a wide spectrum of geoclimatic conditions, but the new technologies were particularly suited for more fertile lands. The large plantation regions of the West had better soils to start with, but in a sense biological innovation made these soils even better. The rapid increase in picking rates before 1840 followed by a leveling off displayed in Panel B of Figure 7 probably reflects the earlier and more rapid diffusion of new varieties in the West.

\section{Biological Innovation:}

We have explored the importance of biological innovation at several points earlier in this article. We can gain further insight into the impact of varieties by examining changes in picking efficiency on the same plantation over time, thus controlling partially for geoclimatic conditions. To qualify for this experiment a plantation had to have records for the years before and after the probable introduction of Mexican cotton. The Locust Grove plantation located in Jefferson County, Mississippi and the Oakland Plantation located in West Feliciana Parish, Louisiana both met this test.

The managers of the Locust Grove plantation kept picking records for 19 consecutive years beginning in $1825 .^{81}$ (The surviving records do not indicate the types of cotton grown.) For the first five years of this period the mean picking rates averaged 84.6 pounds a day. It is likely that Mexican cotton was introduced in these early years. Over the last five years the mean averaged 119.6 pounds. This implies an annual growth rate of about 2.5 percent. The records of Nathaniel Evans (and family) are particularly valuable because they begin well before the widespread introduction of Mexican cotton. In the years 1811-1817, Evans planted Creole Black Seed. The individual picking records for this period

\footnotetext{
${ }^{81}$ Locust Grove Slave Ledger, MUM00275, The Department of Archives and Special Collections, J.D. Williams Library, The University of Mississippi; Barney and Flesher, "Early Nineteenth-Century Productivity Accounting," pp. 275-94.
} 
(1811-13 and 1817) show unweighted mean picking rates of 68.5, 66.6, 83.6, and 64.3 pounds, with an overall mean for the four years of 70.8 pounds. ${ }^{82}$ Nathaniel Evans died in 1819, and the management of his Oakland Plantation passed to his wife Sarah and son John N. Evans. For the 1819 season, the plantation diary enumerates the number of slaves picking and the total amount of cotton picked for 50 days (1,542 slave work days) starting 1 January 1820 and ending 7 April 1820. This was a very late picking season and the mean daily picking rate for this period was only 43.6 pounds per worker. ${ }^{83}$

We can connect the early pre-Mexican picking rates with cotton picking data for 1839-1840 and 1866. For a total of 10 days in September 1839 and November 1840, John N. Evans recorded the number of slaves picking and the total quantity of cotton harvested. The daily mean per slave for this period was 146.7 pounds. ${ }^{84}$ For 1866 we again have individual picking data, albeit only a fragment, consisting of the names and quantity picked by 20 freedmen and women on 18 and 19 October. For these two days the mean picking rate was 157.3 pounds, or over 2 times that recorded in the pre-Mexican era. Because picking rates varied significantly over the season and October would typically be a peak period, it is important to fine-tune our comparison. In the 1811 to 1817 period the mean picking rate during October was 74 pounds. In 1866, 12 of the 40 observations exceeded 200 pounds and one exceeded 300 pounds. By comparison, in October of the four years for which we have data in the 1810s, only two out of the 1,695 observations exceeded 200 pounds. It is most likely that these comparisons significantly understate the differences in picking rates that would have occurred had we had data comparing the 1810s with the late 1850s when slavery still flourished, because picking rates in the later stages of the Civil War and in

\footnotetext{
${ }^{82}$ Nathaniel Evans and Family Papers, 1791-1865, RASP, Ser. I, pt. 2, reel 9, pp. 754-65, 781-85, 794, 804-13.

${ }^{83}$ Ibid., pp. 725-35. Given that these data for the 1819/20 season are for late in the picking season (picking season seldom stretched beyond early January), the average for the entire 1819 season would surely have been higher. On the other hand, the individual picking data for 1813 are limited to the peak of the picking season in late September and October, and more complete data would undoubtedly lead to a significant lowering of that year's recorded mean of 83.6 pounds. In 1839 and 1840 Evans regularly noted the amount of cotton picked every day, but he was less conscientious in noting the number of slaves picking. There were no systematic differences in the quantities picked per day on days that he listed the number of workers, thus it is reasonable to presume that the mean for these ten days was in rough accordance with the more general picking performance.

${ }^{84}$ Ibid., pp. 507-15.
} 
the immediate postwar years fell significantly on other plantations for which we have data. ${ }^{85}$ Overall, the evidence drawn from the Oakland Plantation is consistent with the general trends shown in Figures 5 and $7^{86}$

We noted earlier that there was almost no contemporary testimony extolling the productivity virtues of the gang system. By contrast there was a wealth of statements attributing the increase in picking efficiency to the change in cotton varieties. As an example, in 1852 De Bow's Review reproduced a week of picking data from the 1817 cotton book of G.W. Lovelace of Sicily Island, Louisiana. Over a six day period his slaves averaged 46 pounds of hard to pick Tennessee Green Seed cotton a day, and the most anyone picked in a day was 78 pounds. The article noted that Lovelace "was a good thrifty planter in his time, and had some choice negroes,” but that by 1852 comparable quality hands could pick as much in a day as Lovelace’s pickers could pick in a week because of the change in cotton varieties. ${ }^{87}$

\section{Measured Performance in a Deteriorating Environment}

Our estimates of the actual increase in cotton picking rates only partially capture the full effects of biological innovations because they do not account for negative shocks borne by producers. The economic history of cotton is often written as if the boll weevil, which first appeared in 1892, was the crop’s only serious pest. However, plantation accounts, the nineteenth century southern press, and entomologists' reports clearly show that antebellum planters paid keen attention to the insects and diseases that preyed upon their cotton. Without the infusion of new varieties, yields and picking rates

\footnotetext{
${ }^{85}$ This finding is in line with Shlomowitz's, “Origins,” pp. 557-75, depiction of unsettled labor markets during the postwar years. Although we do not know the variety planted in 1866, we can be fairly confident that it was a Mexican hybrid. The records of Nathaniel's son, John N. Evans, show that between 1845 and 1859, he planted over 10 varieties on his Oakland Plantation, including Mexican, White Mexican, Mastodon, Prolific, and seed from Nutt, Vick, McGhees, Herbert, Hamilton, and other breeders. Nathaniel Evans and Family Papers, 1791-1865, RASP, Ser. I, pt. 2, reel 9, pp. 568-600, and 945-87.

${ }^{86}$ A further indication of the effect of new cottons on picking rates comes from the Stirling Plantation in West Feliciana Parish, Louisiana. For 1847, Stirling's plantation accounts record that the slaves picked Mastodon cotton on four of the 86 picking days. (The cotton picked on the other days was almost undoubtedly of Mexican stock.) Regression analysis controlling for the fixed effects of the 58 individual slaves and for the date in the season reveals that picking rates were 32 percent higher when the Mastodon cotton was picked. Lewis Stirling and Family Papers, 1784-1865, RASP, Ser. I, pt. 2, reel 25.

${ }^{87}$ Kilpatrick, "Historical and Statistical Collections," pp. 632-33.
} 
would have declined significantly in response to the increase in disease, pest, and weed problems. The most menacing disease was cotton rot and the most destructive insects were the boll worm and the cotton worm (known also in the antebellum era as the caterpillar, the army worm, and le chenille). The damage caused by these two insects increased significantly in the period after 1840. In addition, the introduction from foreign lands and subsequent spread of a number of weeds led to a deteriorating environment. As an example, Johnson grass, which became a problem in 1840s, significantly increased the problem of weed control and even with increased diligence sapped cotton yields and picking efficiency. ${ }^{88}$

A disease called "the rot" takes center stage in our discussion because it played a major role in the early transition in varieties. As noted earlier, historians of Mississippi Valley agriculture, where the rot was first mentioned, relate how it wiped out the early Creole Black Seed cotton popular in the region. According to this story, around 1810 to 1815 planters turned to Tennessee Green Seed in desperation, but soon it too became susceptible to rot. Planters then turned to Mexican cotton which gained acceptance in the 1820’s in the Mississippi Valley and which by many accounts was initially totally immune to the disease. ${ }^{89}$ Many of these renditions of rot relied on statements made in agricultural journals, in which observers reflected on events decades after the fact. Such retrospective accounts must be taken with some skepticism given the blurring effect of time on memories. Contemporary newspapers and plantation records offer a more exact sense of the disease’s impact.

The first mention of the disease that we located was in a letter from Natchez, Mississippi Territory published in the Alexandria Gazette on October 12, 1812. “The cotton crops will be late and short, on account of the wetness of the season causing the early balls to rot off." ${ }^{\text {90 }}$ Our search of contemporary newspapers housed in the Mississippi Department of Archives and History found rot first referenced in March 1814 when the commission merchant John Henderson advertised that he had "just

\footnotetext{
${ }^{88}$ For an analysis of this problem in the wheat economy see Olmstead and Rhode, "Red Queen," pp. 929-66. ${ }^{89}$ See for example, Wailes, Report, pp. 143-45; Watkins, King Cotton, pp. 3, 98-99, 164, 167-68, 193; Sydnor, Slavery in Mississippi, p. 182; Gray, History, pp. 677, 689-90; Moore, Emergence, pp. 11-12, and Agriculture, pp. 31-36.

90 "Extract of a letter dated Natchez (M. T.) September 7, 1812,” Alexandria Gazette (12 October 1812), p. 3.
} 
received a quantity of Tennessee Cotton Seed. A change of seed is said to secure the crop against the rot. Planters wishing to make the experiment will do well to apply soon." ${ }^{\text {91 }}$ This account suggests that the change to Tennessee seed was still in the experimental stages several years after some historians have declared that the transition was complete. In the autumn of 1814, letters from New Orleans reported that “rot is destroying the cotton dreadfully."92 In 1815 and 1816 news accounts continued to describe an “alarming” situation in the lower Mississippi Valley with loss rates around fifty percent of the crop. ${ }^{93}$ By 1817 the disease was hitting cotton in Georgia, Alabama Territory, South Carolina, and possibly other areas. One news account reported rot in Alabama Territory in 1817/18, with one-half of the crop destroyed. ${ }^{94}$ In 1819 there was severe damage across a wide range of South Carolina. The switch to Green Seed cottons as a defensive measure clearly continued in some regions into the 1820s. In 1819 James H. Dearing ran an advertisement aimed at Alabama planters offering 2,000 bushels of green cotton seed. The seller implied that the seed was free of rot. ${ }^{95}$ In that same year Georgia planter and former U.S. Senator George W. Troup described the disease’s devastation with crop losses ranging from 25 to 75 percent. Farmers did not limit their search for a cure to Green Seed cotton as Troup requested that an enterprising merchant import seeds from the "Brazils" in the hope that they would prove rot resistant. ${ }^{96}$ In the meantime dire reports continued from Mississippi and Louisiana.

Plantation diaries reinforce the impression that the rot arrived in parts of the Mississippi Valley well after 1810 and that the transitions away from Black Seed to Green Seed varieties and subsequently to Mexican varieties were drawn out processes that took place only after considerable experimentationwith farmers often testing all three varieties simultaneously. The disease hit Nathanial Evans' Louisiana

\footnotetext{
${ }^{91}$ Mississippi Republican (23 March 1814), p. 1. At about the same time another merchant, E. Turner, advertized that "three flat boats loaded with good sound Cotton Seed, of the growth of last year one their way from Madison county to Natchez," Mississippi Republican (2 March 1814), p. 1.

${ }_{92}^{92}$ American Watchman (5 November 1814), p. 2; and Rhode-Island Republican (2 November 1814), p. 3.

${ }^{93}$ For example see the Boston Gazette (20 November 1815), p. 1.

${ }^{94}$ Baltimore Patriot \& Mercantile Advertiser (20 February 1818), p. 2.

${ }^{95}$ The Halcyon and Tombecbe Public Advertiser. From the context this advertisement was published in 1819, probably January.

${ }^{96}$ Troup's appeal was reproduced widely in the press. For different versions see The New-York Columbian (12 October 1819), p. 2, and American Farmer (22 October 1819), p. 237.
} 
plantation hard in 1813. In August he noted that "the Bolls continue to Rott and the forms fall off.” John Palfrey of Attakapas, Louisiana reported in October 1815 that the disease was causing financial embarrassment, and in October 1817 John Bisland of the Natchez area lamented that he expected to "lose one half of the cotton by the rot."97 Louisiana planter David Rees was fighting the disease into the latter part of the 1820s, experimenting with Black Seed, Green Seed, and Mexican cottons. Rees was clearly growing all three varieties at one time and his account suggests that his Black Seed cottons often did better than his Green Seed. The statements of other contemporaries contradict the standard rendition that Green Seed cottons were universally more rot resistant than Black Seed. Alexander Lawton of Beauford, South Carolina reached this conclusion in 1817 when he lamented that "we were visited by the black rot also, which destroy'd from one fourth to one half of the planters crops of green seed cotton, it did not affect black seed cotton.” John Connors of Lancaster, South Carolina also reported that the disease did more damage to his Green Seed than to his Black Seed cotton. ${ }^{98}$ Other plantation documents confirm that the disease caused terrible damage into the mid-1820s in South Carolina. The decline in the frequency of the disease's mention corresponded with the introduction of Mexican cottons and there was a strong causal connection in the minds of many planters. However, early accounts of Mexican cottons also being damaged undermine the frequent claims that the new cottons were totally resistant. Nevertheless, there is little doubt that the transition to Mexican cottons helped ward off losses due to diseases and insects, both because of direct genetic resistance to disease and the cotton's relatively early ripening characteristics. In the 1840s and 1850s both disease and insect problems increased significantly with the reappearance of rot and the aforementioned attacks by the boll worm and cotton worm. These problems further propelled the search for resistant varieties. The upshot is that the measured efficiency improvements that we report in this paper understate the productivity impacts of biological innovation in the antebellum years.

\footnotetext{
${ }^{97}$ Nathaniel Evans and Family Papers, 1791-1865, RASP, Ser. I, pt. 2, reel 9, p. 792; Palfrey Family Papers, 17761918, RASP, Ser. I, pt. 1, reel 1, p. 184; Letter to James Ure, 25 October 1817, Bisland-Shields Family Collection, 1773-1969, RASP, Ser. N, reel 1, p. 522.

${ }_{98} 1822$ and 1826 plantation journals in Davis Rees Papers, 1803-1835, RASP, Ser. H, reel 29, pp. 784-858, and reel 30, pp. 5-15; Alexander Robert Lawton Papers, 1774-1897, RASP, Ser. J, pt. 3, reel 26, p. 672; 22 August 1822, John Connors Papers, SCL/USC, p. 65.
} 


\section{Conclusion}

Technological changes revolutionized southern cotton production in the 60 years preceding the Civil War. The amount of cotton a typical slave picked per day increased about 2.3 percent per year due, primarily, to the introduction and perfection of superior cotton varieties. The increase in picking efficiency correlated with yield and quality improvements which further increased the incentives to grow cotton. These technological changes help make sense of the long-run movements in cotton and slave prices. ${ }^{99}$ They also provide new perspectives on many long-standing issues, including the rapid westward march of cotton production and the slave population; the movement of slaves out of industrial and other urban pursuits into cotton; and the roles of scale, the gang labor system, geography, and other factors in determining productivity. The increase in picking rates and in the quality of U.S. cotton also increased the competitiveness of U.S. producers relative to those in the West Indies, Brazil, India, and Egypt. By the 1850s, the U.S. accounted for over 80 percent of the cotton consumed in Europe and America. British cotton interests were aware of the cotton variety changes underway in the United States, but in spite of repeated efforts they were unable to adapt the new technologies to their Asian colonies. ${ }^{100}$ The locationspecific nature of the innovation process was tailored to fit the environment of the U.S. South and did not immediately spillover to benefit competing regions. The United States maintained the quality advantage in world cotton markets until the boll weevil largely wiped out the production of long and medium staple varieties in the American South roughly 40 years after the Civil War.

To put the pre-Civil War increase in picking efficiency into perspective, the early (circa 1860) mechanical reaper, which represents the textbook example of an antebellum laborsaving mechanical innovation, increased wheat harvest labor efficiency relative to using a cradle by roughly 50 to 100

\footnotetext{
${ }^{99}$ We have focused on biological innovations, but cotton farmers also adopted many laborsaving mechanical innovations. As two examples, scrapers that allowed hands to weed about two-thirds more land per day than was possible with traditional hoeing gained popularity in the 1840s, and machine seeders became common by the 1850s. Gray, History, pp. 689-702, 797. Adjustments in the time of planting, the density of seeding, and in plowing practices, all effected land and labor productivity. Moore, Agriculture, pp. 46-47, and Emergence, pp. 30-34, 50.

${ }^{100}$ Compiled from Dana, Cotton From Seed to Loom, p. 251.
} 
percent. ${ }^{101}$ The data on the impact of Mexican hybrids suggest that their impact on cotton harvest efficiency likely surpassed that of the reaper on the grain harvest in the antebellum era. ${ }^{102}$ The total impact of the Mexican hybrids would of course have been even greater because of their effects on yields and cotton quality. The mechanical reaper had no parallel impact on either yields or quality. But the Mexican cottons did have one important point in common with the reaper and many other mechanical innovations. The new easier picking cotton varieties helped smooth out the peak-load labor demands so that the labor hours needed for the harvest more closely approximated those needed for non-harvest tasks. This led to a decline in the often-heard comment that farmers planted more cotton than they could pick, and (as with the diffusion of the reaper) it presumably led to an increase in acres planted. These were some of the ways that biological innovations reshaped the opportunities cotton farmers faced and fundamentally altered the antebellum southern economy.

\footnotetext{
${ }^{101}$ In actuality it was the reaper and the use of additional horsepower that yielded this result.

${ }^{102}$ Mechanical technologies were not static - the reaper of 1860 represented a step in a sequence of developments that eventually led to the grain combine. But the biological learning of the pre-1860 era also laid the foundation for later spinoffs important in the development of American agriculture.
} 


\section{References}

Affleck, Thomas. "The Early Days of Cotton Growing in the South-West." De Bow's Review 10, no. 6 (1851): 668-9.

Affleck, Thomas. Affleck's Southern Rural Almanac, and Plantation and Garden Calendar for 1854. Washington, MS: Thomas Affleck, 1853.

Alabama State Intelligencer [Tuscaloosa, AL], Various issues.

Alexandria Gazette [Alexandria, VA], 12 October 1812.

American Farmer [Baltimore, MD], Various issues.

American Mercury [Hartford, CT], 10 October 1826.

American Watchman [Wilmington, DE], 5 November 1814.

Anderson, Ralph, and Robert E. Gallman. "Slaves as Fixed Capital: Slave Labor and Southern Economic Development." Journal of American History 64, no. 1 (1977): 24-46.

Baltimore Patriot \& Mercantile Advertiser [Baltimore, MD], 20 February 1818.

Barney, D., and D. L. Flesher. "Early Nineteenth-Century Productivity Accounting: The Locust Grove Slave Ledger." Accounting, Business and Financial History 4, no. 2 (1994): 27594.

Bassett, John Spencer, ed. Correspondence of Andrew Jackson. Vol. 5. Washington, DC: Carnegie Institution of Washington, 1926-1935.

Boston Gazette [Boston, MA], 20 November 1815.

Brubaker, Curt L., and Jonathan F. Wendel. "Reevaluating the Origin of Domesticated Cotton (Gossypium Hirsutum; Malvanceae) Using Nuclear Restriction Fragment Length Polymorphisms (RFLPs)." American Journal of Botany 81, no. 10 (1994): 1309-26. 
Brubaker, Curt L., E. M. Bourland, and Jonathan F. Wendel. "The Origin and Domestication of Cotton." In Cotton: Origin, History, Technology, and Production, edited by C. Wayne Smith and J. Tom Cothren, 3-31. New York: John Wiley \& Sons, 1999.

Campbell, John Douglas. "The Gender Division of Labor, Slave Reproduction, and the Slave Family Economy on Southern Cotton Plantations, 1800-1864." PhD, University of Minnesota, 1988.

Carter, Susan B., et al., eds. Historical Statistics of the United States: Earliest Times to the Present. Millennial ed. 5 Vols. New York, NY: Cambridge University Press, 2006.

Chaplin, Joyce E. An Anxious Pursuit: Agricultural Innovation and Modernity in the Lower South, 1730-1815. Chapel Hill: University of North Carolina Press, 1993.

Claiborne, J. F. H. Mississippi, as a Province, Territory, and State with Biographical Notices of Eminent Citizens. 1. Jackson, MS: Power and Barksdale, 1880.

Collings, Gilbeart H. Production of Cotton. New York: John Wiley, 1926.

Columbian Museum [Savannah, GA], 27 March 1798.

Conrad, Alfred H., and John R. Meyer. The Economics of Slavery and Other Studies in Econometric History. Chicago: Aldine, 1964.

Craig, Lee A., and Thomas Weiss. Rural Agricultural Workforce by County, 1800 to 1900 [Computer file]. Oxford, OH: EH.Net, Miami University [distributor], 1998. Available from http://eh.net/databases/agriculture/.

Craig, Lee A., Michael R. Haines, and Thomas Weiss. Development, Health, Nutrition, and Mortality: The Case of the 'Antebellum Puzzle' in the United States. NBER Working Paper Series on Historical Factors in Long Run Growth, Historical Paper 130. Cambridge, MA: National Bureau of Economic Research, 2000. 
Craig, Lee A., Michael R. Haines, and Thomas Weiss. U.S. Censuses of Agriculture, by County, 1840-1880 [Computer file]. Raleigh, NC: Unpublished files graciously provided by the authors, Dept. of Economics, North Carolina State University, 2000.

The Cultivator [Albany, NY], June 1840.

Dana, William B. Cotton From Seed to Loom: A Handbook of Facts for the Daily Use of Producer, Merchant and Consumer. New York: William B. Dana \& Co., 1878.

Davis, Edwin A., ed. Plantation Life in the Florida Parishes of Louisiana, 1836-1846, As Reflected in the Diary of Bennet H. Barrow. New York: AMS Press, 1967.

Donnell, E. J. Chronological and Statistical History of Cotton. Reprint of 1872 ed. Wilmington, DE: Scholarly Resources, 1973.

Du Pre, Lewis. Observations on the Culture of Cotton. Georgetown, GA: Elliot and Burd, 1799. Dunbar, William. Life, Letters, and Papers of William Dunbar: of Elgin, Morayshire, Scotland, and Natchez, Mississippi: Pioneer Scientist of the Southern United States. Edited by Eron Rowland. Jackson, MI: Press of the Mississippi Historical Society, 1930.

Farmer \& Gardener, and Live-Stock Breeder and Manager [Baltimore, MD], 22 December 1835.

Farmers' Register [Shellbanks, VA], June 1834.

Fogel, Robert W. The Slavery Debates, 1952-1990: A Memoir. Baton Rouge: Louisiana State University Press, 2003.

Fogel, Robert W. Without Consent or Contract: The Rise and Fall of American Slavery. New York: W. W. Norton, 1989. 
Fogel, Robert W., and Stanley L. Engerman, eds. Without Consent or Contract: The Rise and Fall of American Slavery: Technical Papers. 1st ed. Vol. 1, Markets and Production. New York: Norton, 1992.

Fogel, Robert W., and Stanley L. Engerman. "Explaining the Relative Efficiency of Slave Agriculture in the Antebellum South." American Economic Review 12 (1977): 275-96.

Fogel, Robert W., and Stanley L. Engerman. Time on the Cross: The Economics of American Negro Slavery. 1st ed. Boston, MA: Little, Brown, 1974.

Foust, James D. The Yeoman Farmer and Westward Expansion of U. S. Cotton Production. New York: Arno Press, 1975, c1969.

Fryxell, Paul A. The Natural History of the Cotton Tribe (Malvaceae, Tribe Gossypieae). 1st ed. College Station, TX: Texas A\&M University Press, 1979.

Gallman, Robert E. "Self-Sufficiency in the Cotton Economy of the Antebellum South." Agricultural History 44, no. 1 (1970): 5-23.

Genius of Universal Emancipation [Mount Pleasant, OH], 30 October 1897.

Georgia Gazette [Savannah, GA], 30 April 1801.

Goldin, Claudia. Urban Slavery in the American South, 1820-1860: A Quantitative History. Chicago: University of Chicago Press, 1976.

Gray, Lewis Cecil. History of Agriculture in the Southern United States to 1860. Reprint ed. Vol. 2. New York: Peter Smith, 1941.

Halcyon and Tombecbe Public Advertiser [St. Stephen's, AL], ca. 1819.

Handy, R. B. "History and General Statistics of Cotton." In The Cotton Plant: Its History, Botany, Chemistry, Culture, Enemies, and Uses, edited by Charles Dabney, 17-66. Washington, DC: GPO, 1896. 
Hayami, Yujiro, and Vernon Ruttan. Agricultural Development: An International Perspective. Rev. and exp. ed. Baltimore: Johns Hopkins University Press, 1985.

Hemphill, W. Edwin, ed. The Papers of John C. Calhoun. Vol. 9, 1824-1825. Columbia, SC: University of South Carolina Press, 1976.

Ingraham, Joseph Hilt. The Southwest by a Yankee. Vol. 2. New York: Harper and Brothers, 1835.

Kilpatrick, Dr. "Historical and Statistical Collections of Louisiana: The Parish of Catahoula, Part 2." De Bow's Review 12, no. 6 (1852): 631-46.

Lakwete, Angele. Inventing the Cotton Gin: Machine and Myth in Antebellum America. Baltimore: Johns Hopkins University Press, 2003.

Landes, David S. The Unbound Prometheus: Technological Change and Industrial Development in Western Europe from 1750 to the Present. Cambridge, UK: Cambridge University Press, 1969.

Lebergott, Stanley. The Americans: An Economic Record. New York: Norton, 1984.

Lee, Susan P. The Westward Movement of the Cotton Economy, 1840-1860: Perceived Interests and Economic Reality. New York: Columbia University Press, 1975.

Lyman, Joseph B. Cotton Culture. New York: Orange Judd, 1868.

Mendenhall, Marjorie Stratford. "A History of Agriculture in South Carolina 1790 to 1860: An Economic and Social Study." PhD diss., University of North Carolina, 1940.

Metzer, Jacob. "Rational Management, Modern Business Practices, and Economies of Scale in the Ante-bellum Southern Plantations." Explorations in Economic History 12, no. 2 (1975): 123-50.

Mississippi Republican [Natchez, MS], 23 March 1814. 
Moore, John Hebron, and Margaret D. Moore. Cotton Culture on the South Carolina Frontier: Journal of John Baxter Fraser, 1804-1807. N.p.: Privately printed, 1997.

Moore, John Hebron. "Cotton Breeding in the Old South." Agricultural History 30, no. 3 (1956): 95-104.

Moore, John Hebron. Agriculture in Ante-Bellum Mississippi. New York: Bookman Associates, 1958.

Moore, John Hebron. The Emergence of the Cotton Kingdom in the Old Southwest, Mississippi, 1770-1860. Baton Rouge: Louisiana State University Press, 1988.

Morgan, Philip D. "Task and Gang Systems: The Organization of Labor on New World Plantations." In Work and Labor in Early America, edited by Stephen Innes, 189-220. Chapel Hill, NC: Published for the Institute of Early American History and Culture by the University of North Carolina Press, 1988.

New York Times [New York, NY], 26 July 1853.

The New-York Columbian [New York, NY], 12 October 1819.

Norse, Clifford C. "The Southern Cultivator, 1843-1861." PhD diss., Florida State University, 1969.

Olmstead, Alan L., and Paul W. Rhode. "The Red Queen and the Hard Reds: Productivity Growth in American Wheat, 1800-1940." Journal of Economic History 62, no. 4 (2002): 929-66.

Olmstead, Alan L., and Paul W. Rhode. Creating Abundance: Biological Innovation and American Agricultural Development. New York: Cambridge University Press, forthcoming 2008. 
Parker, William N. "Labor Productivity in Cotton Farming: The History of a Research." Agricultural History 53, no. 1 (1979): 228-44.

Parker, William N., and Robert E. Gallman. Southern Farms Study, 1860 [Computer file]. Ann Arbor, MI: Inter-university Consortium for Political and Social Research [producer and distributor], 1991. Available from http://www.icpsr.umich.edu/cocoon/ICPSR/STUDY/07419.xml [Membership required for access].

Passell, Peter, and Gavin Wright. "The Efficiency of Pre-Civil War Territorial Expansion on the Price of Slaves." Journal of Political Economy 80, no. 6 (1972): 1188-202.

Phillips, M. W. "Mexican Cotton Seed." Commercial Review of the South and West 2, no. 4 (1846): 279-80.

Phillips, Ulrich B. American Negro Slavery. Baton Rouge, LA: Louisiana State University Press, 1966.

Poehlman, John Milton, and David Allen Sleper. Breeding Field Crops. 4th ed. Ames: Iowa State University Press, 1995.

Porcher, Richard Dwight, and Sarah Fick. The Story of Sea Island Cotton. 1st ed. Charleston, SC: Wyrick, 2005.

Purseglove, J. W. Tropical Crops: Dicotyledons. Vol. 2. New York: John Wiley, 1968.

Ramsdell, Charles W. "The Natural Limits of Slavery Expansion." Mississippi Valley Historical Review 16, no. 2 (1929): 151-71.

Rhode-Island Republican [Newport, RI], 2 November 1814.

Rosengraten, Theodore. Tombee: Portrait of a Cotton Planter. New York: William Morrow, 1986. 
Scheiber, Harry N., Harold G. Vattner, and Harold U. Faulkner. American Economic History. New York: Harper \& Row, 1976.

Shlomowitz, Ralph. "The Origins of Southern Sharecropping." Agricultural History 53, no. 3 (1979): 557-75.

Slavery and the Making of America. [Web site]. Washington, DC: Public Broadcasting Service. Available from http://www.pbs.org/wnet/slavery/experience/living/e4.html.

Smith, C. Wayne. Crop Production: Evolution, History, and Technology. New York: John Wiley and Sons, 1995.

Stampp, Kenneth M., ed. Records of Ante-bellum Southern Plantations from the Revolution through the Civil War [Microfilm]. Frederick, MD: University Publications of America, 1985-2000.

Stephens, S. G. "Some Observations of Photoperiodism and the Development of Annual Forms of Domesticated Cottons." Economic Botany 30 (1975): 409-18.

Stephens, S. G. "The Origin of Sea Island Cotton." Agricultural History 50, no. 2 (1976): 391-9.

Sydnor, Charles S. Slavery in Mississippi. Gloucester, MA: P. Smith, 1965, c1933.

Turner, Joseph Addison. The Cotton Planter's Manual: Being a Compilation of Facts from the Best Authorities on the Culture of Cotton. New York: C. M. Saxton and Co., 1857.

Tyler, Frederick J. "Varieties of American Upland Cotton." U.S. Bureau of Plant Industry Bulletin, no. 163 (1910).

U.S. Dept. of Agriculture. Atlas of American Agriculture. 8 vols. Washington, DC: GPO, 19171935.

Vicksburg Sentinel [Vicksburg, MS], 7 July 1847. 
Wailes, B. C. L. Report on the Agriculture and Geology of Mississippi. Jackson, MS: State Printer, 1854.

Ware, Jacob Osborn. "Origin, Rise and Development of American Upland Cotton Varieties and their Status at Present." University Of Arkansas College of Agriculture, Agricultural Experiment Station Mimeo (1950).

Ware, Jacob Osborn. "Plant Breeding and the Cotton Industry." In U.S. Dept. of Agriculture Yearbook 1936, 657-744. Washington, DC: GPO, 1936.

Watkins, James L. King Cotton: A Historical and Statistical Review, 1790 to 1908. Reprint of 1908 ed. New York: Negro Universities Press, 1969.

Watt, George. The Wild and Cultivated Cotton Plants of the World. London: Longmans, Green, 1907.

Wendel, Jonathan F., and Richard C. Cronn. "Polyploidy and the Evolutionary History of Cotton." Advances in Agronomy 78 (2003): 139-86.

Wendel, Jonathan F., Curt L. Brubaker, and A. Edward Percival. "Genetic Diversity in Gossypium Hirsutum and the Origin of Upland Cotton." American Journal of Botany 79, no. 11 (1992): 1291-310.

Whartenby, Franklee Gilbert. Land and Labor Productivity in United States Cotton Production, 1800-1840. New York: Arno Press, 1977.

Williams, Robert W. "Thomas Affleck: Missionary to the Planter, the Farmer, and the Gardener." Agricultural History 31, no. 3 (1957): 40-8.

Wright, Gavin. "The Efficiency of Slavery: Another Interpretation." American Economic Review 69, no. 1 (1979): 219-26. 
Wright, Gavin. Slavery and American Economic Development. Baton Rouge, LA: Louisiana State University Press, 2006.

Wright, Gavin. The Political Economy of the Cotton South: Households, Markets, and Wealth in the Nineteenth Century. New York: Norton, 1978.

Archives and collections referred to in text.

Center for American History, University of Texas (Austin, TX).

Leyendecker Family. Papers, 1817-1981.

Department of Archives and Special Collections, J.D. Williams Library, The University of Mississippi (University, MS).

Locust Grove Slave Ledger. MUM00275.

Historic Natchez Foundation (Natchez, MS).

Jenkins, John Carmichael. Elgin Plantation Journal.

Huntington Library, Art Collections and Botanical Gardens (San Marino, CA).

Nutt, Rush. Papers of Rush and Haller Nutt, 1805-1933 (Bulk 1817-1862). MssNU 1-365

Louisiana and Lower Mississippi Valley Collections, Louisiana State University Libraries (Baton Rouge, LA).

Bacon, Edmund. Letters, 1802-1820. Mss. 2178.

Ohio Historical Center Archives Library (Columbus, OH). 
Eustatia Plantation, Mississippi, Account Book 1861.

Southern Historical Collection, Wilson Library, University of North Carolina (Chapel Hill, NC).

Baker, Everard Green. Papers, 1848-1876. Coll. 41.

Croom, Hardy Bryan. Papers, 1822-1838. Coll. 3772.

Eaton, John Rust. Papers, 1794-1815. Coll. 234-z.

Gould, William Proctor. Diary, 1828-1856. M-1192.

Minor Family. Papers, 1763-1900. Coll. 1564.

Whitmore, Charles. Plantation Journal, 1834-1864. Coll. 2406.

South Carolina Historical Society (Charleston, SC).

Rivers, Elias Lynch. Family Papers, 1750-1913. Coll. 51-542.

South Caroliniana Library, University of South Carolina (Columbia, SC).

Connors, John. Papers.

Guignard Family. Papers, 1742-1952.

Reynolds Family. Papers, 1837-1958.

Richardson, William Guignard. Papers, 1800-1849.

Townes Family. Papers, 1784-1967.

Special and Archival Collections, Texas A\&M University (College Station, TX).

Affleck, Thomas. Papers. 
Table 1: Primal-Side and Dual-Side Indicators of Cotton Productivity Growth

\begin{tabular}{lrrrr} 
& \multicolumn{4}{c}{ Percent Growth per Annum } \\
& $1800-1860$ & $1800-1820$ & $1820-1840$ & $1840-1860$ \\
Primal Side & 6.61 & 7.61 & 6.96 & 5.24 \\
\hline Cotton Output & & & & \\
$\quad$ Cotton Labor Force & & 5.99 & & \\
$\quad$ Woodbury & & 5.99 & 5.03 & \\
$\quad$ Whartenby & & & & \\
$\quad$ Estimates based on Craig-Weiss Ag LF & 2.70 & 3.04 & 2.43 & 2.63 \\
$\quad$ Slave Ag LF in cotton states & 4.22 & 5.13 & 4.14 & 3.38 \\
$\quad$ Slave Ag LF in cotton counties & 3.85 & 4.39 & 3.99 & 3.18 \\
$\quad$ Total Ag LF in cotton counties & & & & \\
$\quad$ & & & & \\
Dual Side & -0.53 & 0.06 & -2.63 & 1.11 \\
Real prices & 1.92 & 2.47 & -0.07 & 3.46
\end{tabular}

Sources: Carter et al., Historical Statistics, table Da756 (cotton output); table Bb210 (slave prices); table Cc222 (cotton prices); and table Cc113 (deflator). Whartenby and Woodbury labor force data are from Whartenby, Land and Labor Productivity, pp. 67-71. Our figures are based on Slave and Total Agricultural Labor Force (aged 10 and over) from Craig and Weiss, Rural Agricultural Workforce, in cotton states (VA, NC, SC, GA, FL, TN, AL, MS, LA, AR, and TX), and in cotton counties as identified in 1800 (53 counties), 1820 (121), and 1840 (267) in the cotton production maps of Stine and Baker in USDA, Atlas, pt. 5, sec. A, pp. 16-17, and as identified in the Census of Agriculture of 1840 (233 counties) and 1860 (409) as reporting 1,000 or more 400-lb. bales, using Craig, Haines, and Weiss, Development, Health, Nutrition, and Mortality, and U.S. Censuses of Agriculture by County. 
Table 2: Deciphering Daily Picking Rates, 1801-1862

Log (Mean Picking) Upland Cotton Operations

(2)

(3)

\begin{tabular}{|c|c|c|c|c|c|c|}
\hline Constant & $\begin{array}{l}\text { Coeff } \\
\text { Rob. SE }\end{array}$ & $\begin{array}{r}4.387 \\
(0.0324)\end{array}$ & $\begin{array}{r}3.787 \\
(0.0831)\end{array}$ & $\begin{array}{r}3.317 \\
(0.1089)\end{array}$ & $\begin{array}{r}3.560 \\
(0.0957)\end{array}$ & $\begin{array}{r}3.504 \\
(0.3546)\end{array}$ \\
\hline Year_30 & $\begin{array}{l}\text { Coeff } \\
\text { Rob. SE }\end{array}$ & $\begin{array}{r}0.0245 \\
(0.00157)\end{array}$ & $\begin{array}{r}0.0194 \\
(0.00161)\end{array}$ & $\begin{array}{r}0.0197 \\
(0.00191)\end{array}$ & $\begin{array}{r}0.00609 \\
(0.00238)\end{array}$ & $\begin{array}{r}0.00606 \\
(0.00343)\end{array}$ \\
\hline Year_30_Sq & $\begin{array}{l}\text { Coeff } \\
\text { Rob. SE }\end{array}$ & $\begin{array}{l}-0.000416 \\
0.000076)\end{array}$ & $\begin{array}{r}-0.000258 \\
(0.000073)\end{array}$ & $\begin{array}{r}-0.000214 \\
(0.000073)\end{array}$ & $\begin{array}{r}-0.000228 \\
(0.000178)\end{array}$ & $\begin{array}{r}-0.000233 \\
(0.00020)\end{array}$ \\
\hline Log (Pickers) & $\begin{array}{l}\text { Coeff } \\
\text { Rob. SE }\end{array}$ & & $\begin{array}{r}0.1956 \\
(0.0261)\end{array}$ & $\begin{array}{r}0.1434 \\
(0.0261)\end{array}$ & & $\begin{array}{r}0.0147 \\
(0.1198)\end{array}$ \\
\hline Male & $\begin{array}{l}\text { Coeff } \\
\text { Rob. SE }\end{array}$ & & & $\begin{array}{r}0.5939 \\
(0.1404)\end{array}$ & & \\
\hline Non-Peak & $\begin{array}{l}\text { Coeff } \\
\text { Rob. SE }\end{array}$ & & & $\begin{array}{r}-0.2239 \\
(0.0941)\end{array}$ & & \\
\hline New South & $\begin{array}{l}\text { Coeff } \\
\text { Rob. SE }\end{array}$ & & & $\begin{array}{r}0.4509 \\
(0.0424)\end{array}$ & & \\
\hline $\begin{array}{l}\text { R-squared } \\
\text { No. of Obs. }\end{array}$ & & $\begin{array}{r}0.249 \\
474\end{array}$ & $\begin{array}{r}0.356 \\
462\end{array}$ & $\begin{array}{r}0.557 \\
396\end{array}$ & $\begin{array}{r}0.125 \\
35\end{array}$ & $\begin{array}{r}0.150 \\
31\end{array}$ \\
\hline $\begin{array}{l}\text { Summary } \\
\text { Statistics: }\end{array}$ & Variable & Obs & Mean & Std. Dev. & Min & $\operatorname{Max}$ \\
\hline Upland Cotton & $\begin{array}{l}\text { Lmean } \\
\text { Log(Pickers) }\end{array}$ & $\begin{array}{l}474 \\
462\end{array}$ & $\begin{array}{l}4.621 \\
3.041\end{array}$ & $\begin{array}{l}0.457 \\
0.699\end{array}$ & $\begin{array}{l}3.103 \\
0.639\end{array}$ & $\begin{array}{l}5.661 \\
4.504\end{array}$ \\
\hline & Year_30 & 474 & 17.926 & 12.726 & -29 & 32 \\
\hline & Male & 409 & 0.504 & 0.123 & 0.128 & 1 \\
\hline & Non-Peak & 411 & 0.191 & 0.199 & 0 & 1 \\
\hline & New South & 474 & 0.783 & 0.412 & 0 & 1 \\
\hline$\underline{\text { Sea Island }}$ & $\begin{array}{l}\text { Lmean } \\
\text { Log(Pickers) } \\
\text { Year_30 }\end{array}$ & $\begin{array}{l}35 \\
31 \\
35\end{array}$ & $\begin{array}{r}3.536 \\
2.757 \\
12.200\end{array}$ & $\begin{array}{r}0.308 \\
0.642 \\
17.148\end{array}$ & $\begin{array}{r}2.984 \\
1.227 \\
-29\end{array}$ & $\begin{array}{r}4.135 \\
3.864 \\
31\end{array}$ \\
\hline
\end{tabular}

Notes: Year_30 = Crop Year-1830; Year_30_Sq = Year_30^2; Log(Pickers) = log (average number of pickers per day); Male = percent of picking obs. for males; Non-Peak = percent of picking obs. in months other than September, October, and November; New South $=1$ if plantation is in Alabama, Arkansas, Florida, Louisiana, Mississippi, Tennessee, or Texas, $=0$ otherwise. Standard Errors are robust. Source: Compiled from Slave Cotton Plantation Dataset, 2008.

Sea Island Operations

(1) (2) 
Table 3: Fixed Effects Model of Daily Picking Rates for Plantations with Observations in Multiple Years Log (Mean Picking) Upland Cotton Operations

(1) (2) (3)

$\begin{array}{llrrr}\text { Constant } & \text { Coeff } & 4.359 & 4.364 & 4.357 \\ & \text { Rob. SE } & (0.0469) & (0.1190) & (0.1407) \\ \text { Year_30 } & \text { Coeff } & 0.0174 & 0.0182 & 0.0191 \\ & \text { Rob. SE } & (0.00379) & (0.0041) & (0.0034) \\ \text { Year_30_Sq } & \text { Coeff } & -0.000074 & -0.000082 & -0.00012 \\ & \text { Rob. SE } & (0.000100) & (0.00010) & (0.000077) \\ \text { Log(Pickers) } & \text { Coeff } & & & \\ & \text { Rob. SE } & & (0.0404) & (0.0353) \\ \text { Male } & \text { Coeff } & & & \\ & \text { Rob. SE } & & & 0.3554 \\ \text { Non-Peak } & \text { Coeff } & & & (0.1564) \\ & \text { Rob. SE } & & & -0.2539 \\ \text { R-squared } & & & & (0.0963) \\ \text { No. of Obs. } & & 0.854 & 0.847 & 0.888 \\ \text { Categories } & & 428 & 417 & 360 \\ & & 87 & 87 & 75\end{array}$

Source: Compiled from Slave Cotton Plantation Dataset, 2008. 
Table 4: Upland Picking Rates in Old and New South

\begin{tabular}{|c|c|c|c|c|c|}
\hline \multicolumn{2}{|c|}{ Log (Mean Picking) } & \multicolumn{2}{|c|}{$\begin{array}{l}\text { Old South } \\
\text { (1) }\end{array}$} & \multicolumn{2}{|c|}{$\begin{array}{l}\text { New South } \\
\text { (1) }\end{array}$} \\
\hline Constant & $\begin{array}{l}\text { Coeff } \\
\text { Rob. SE }\end{array}$ & $\begin{array}{r}3.961 \\
(0.0610)\end{array}$ & $\begin{array}{r}3.373 \\
(0.209)\end{array}$ & $\begin{array}{r}4.478 \\
(0.0300)\end{array}$ & $\begin{array}{r}3.877 \\
(0.138)\end{array}$ \\
\hline Year_30 & $\begin{array}{l}\text { Coeff } \\
\text { Rob. SE }\end{array}$ & $\begin{array}{r}0.0156 \\
(0.00132)\end{array}$ & $\begin{array}{r}0.0180 \\
(0.00242)\end{array}$ & $\begin{array}{r}0.0283 \\
(0.00263)\end{array}$ & $\begin{array}{r}0.0252 \\
(0.00236)\end{array}$ \\
\hline Year_30_Sq & $\begin{array}{l}\text { Coeff } \\
\text { Rob. SE }\end{array}$ & $\begin{array}{r}-0.000025 \\
(0.000097)\end{array}$ & $\begin{array}{r}0.000062 \\
(0.00011)\end{array}$ & $\begin{array}{r}-0.00054 \\
(0.00010)\end{array}$ & $\begin{array}{r}-0.00040 \\
(0.000088)\end{array}$ \\
\hline Log (Pickers) & $\begin{array}{l}\text { Coeff } \\
\text { Rob. SE }\end{array}$ & & $\begin{array}{r}-0.290 \\
(0.0856)\end{array}$ & & $\begin{array}{r}0.139 \\
0.0282\end{array}$ \\
\hline Male & $\begin{array}{l}\text { Coeff } \\
\text { Rob. SE }\end{array}$ & & $\begin{array}{r}1.084 \\
(0.224)\end{array}$ & & $\begin{array}{r}0.401 \\
(0.175)\end{array}$ \\
\hline Non-Peak & $\begin{array}{l}\text { Coeff } \\
\text { Rob. SE }\end{array}$ & & $\begin{array}{r}0.0760 \\
(0.224)\end{array}$ & & $\begin{array}{r}-0.267 \\
(0.0978)\end{array}$ \\
\hline $\begin{array}{l}\text { R-squared } \\
\text { No. of Obs. }\end{array}$ & & $\begin{array}{r}0.368 \\
103\end{array}$ & $\begin{array}{r}0.596 \\
68\end{array}$ & $\begin{array}{r}0.304 \\
371\end{array}$ & $\begin{array}{r}0.450 \\
328\end{array}$ \\
\hline
\end{tabular}

\begin{tabular}{|c|c|c|c|c|c|c|}
\hline $\begin{array}{l}\text { Summary } \\
\text { Statistics: }\end{array}$ & Variable & Obs & Mean & Std. Dev. & Min & $\operatorname{Max}$ \\
\hline \multirow[t]{5}{*}{ Old South } & Lmean & 103 & 4.227 & 0.358 & 3.206 & 4.905 \\
\hline & Log(Pickers) & 103 & 2.736 & 0.666 & 1.099 & 4.504 \\
\hline & Year_30 & 103 & 17.864 & 14.180 & -29 & 32 \\
\hline & Male & 77 & .0472 & 0.152 & 0.143 & 1 \\
\hline & Non-Peak & 79 & 0.116 & 0.149 & 0 & 1 \\
\hline \multirow[t]{5}{*}{$\underline{\text { New South }}$} & Lmean & 371 & 4.731 & 0.419 & 3.103 & 5.661 \\
\hline & Log(Pickers) & 359 & 3.128 & 0.685 & 0.639 & 4.431 \\
\hline & Year_30 & 371 & 17.951 & 12.312 & -25 & 32 \\
\hline & Male & 332 & 0.512 & 0.114 & 0.128 & 0.838 \\
\hline & Non-Peak & 332 & 0.208 & 0.205 & 0 & 1 \\
\hline
\end{tabular}

Source: Compiled from Slave Cotton Plantation Dataset, 2008. 
Table 5: Fixed Effect Models for Old and New South Upland Operations with Observations in Multiple Years Log (Mean Picking) Old South

Constant

Coeff 3.879

(0.0975)

Year_30

Coeff

Rob. SE

0.0197

$(0.00437)$

0.0000052

(0.000117)

Rob. SE

Log (Pickers)

$$
\text { Coeff }
$$

Rob. SE

Male Coeff

Rob. SE

Non-Peak

Coeff

Rob. SE
(1)

(3)

4.057
$(0.449)$

0.0143

(0.00642)

$-0.000063$

(0.00012)

$-0.0254$

(0.108)

0.0641

(0.294)

$-0.371$

$(0.203)$

0.789

88

18

0.897

56

11
New South

(1)

$\begin{array}{rr}4.478 & 4.411 \\ (0.636) & (0.153) \\ & \\ 0.0167 & 0.0216 \\ (0.0075) & (0.0060) \\ & \\ -0.000083 & -0.00019 \\ (0.00020) & (0.00014) \\ & -0.0386 \\ & (0.0372) \\ & 0.389 \\ & (0.185)\end{array}$

$-0.245$

(0.103)

$\begin{array}{rr}0.824 & 0.855 \\ 340 & 304 \\ 69 & 64\end{array}$

Categories

Source: Compiled from Slave Cotton Plantation Dataset, 2008. 
Figure 1: Cotton Production and Slave and Cotton Prices

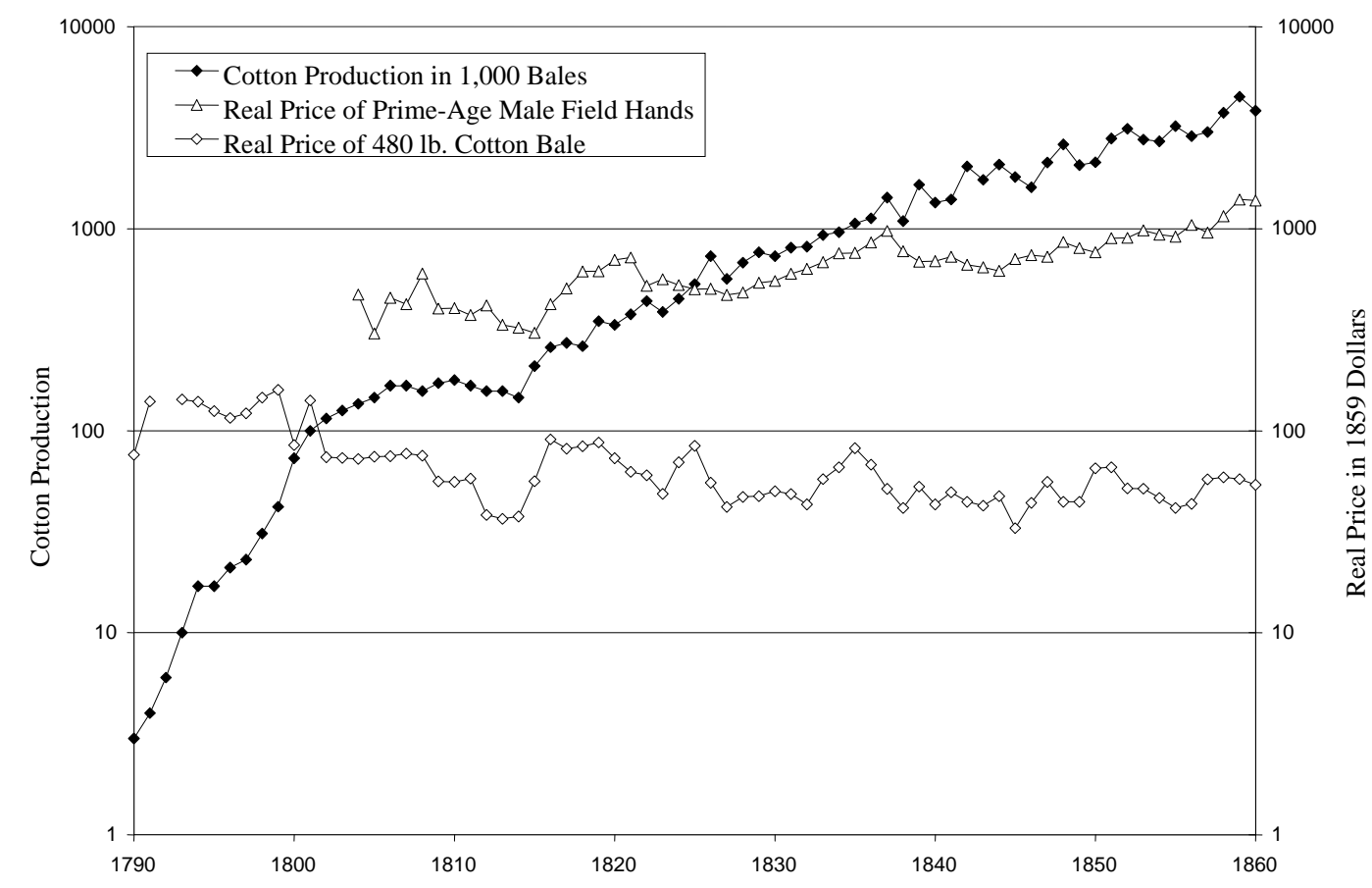

Sources: Carter et al., Historical Statistics, Table Da756 (cotton output); Table Bb210 (slave prices); Table Cc222 (cotton prices); and Table Cc113 (deflator). 
Figure 2: David Dickson’s 1854 Seed Advertisement

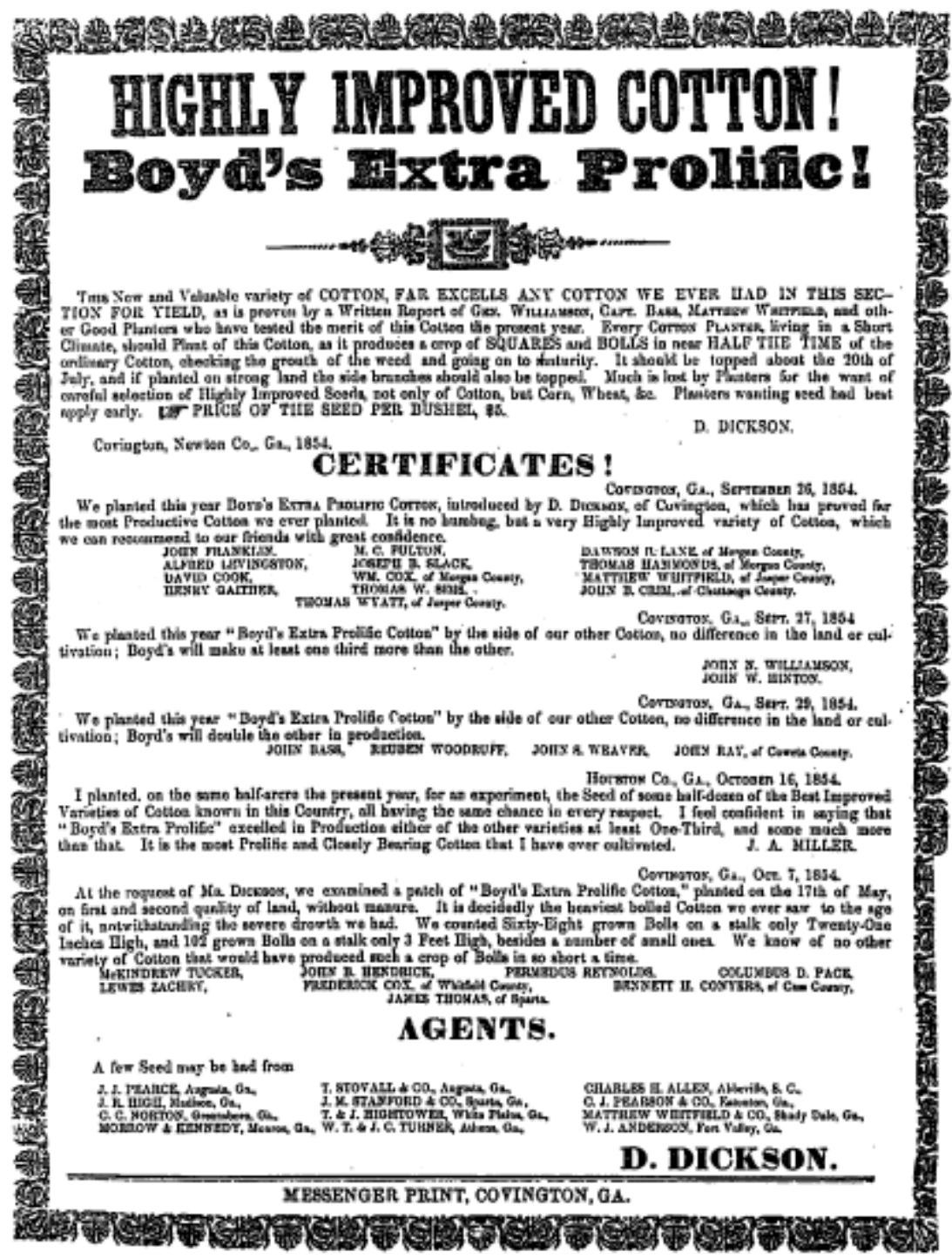

Source: Hargrett Library Broadside Collection, 1850-1859, Mss. 2622, Hargrett Rare Book \& Manuscript Library, University of Georgia Libraries. 
Figure 3: Sample from Eustatia Cotton Book

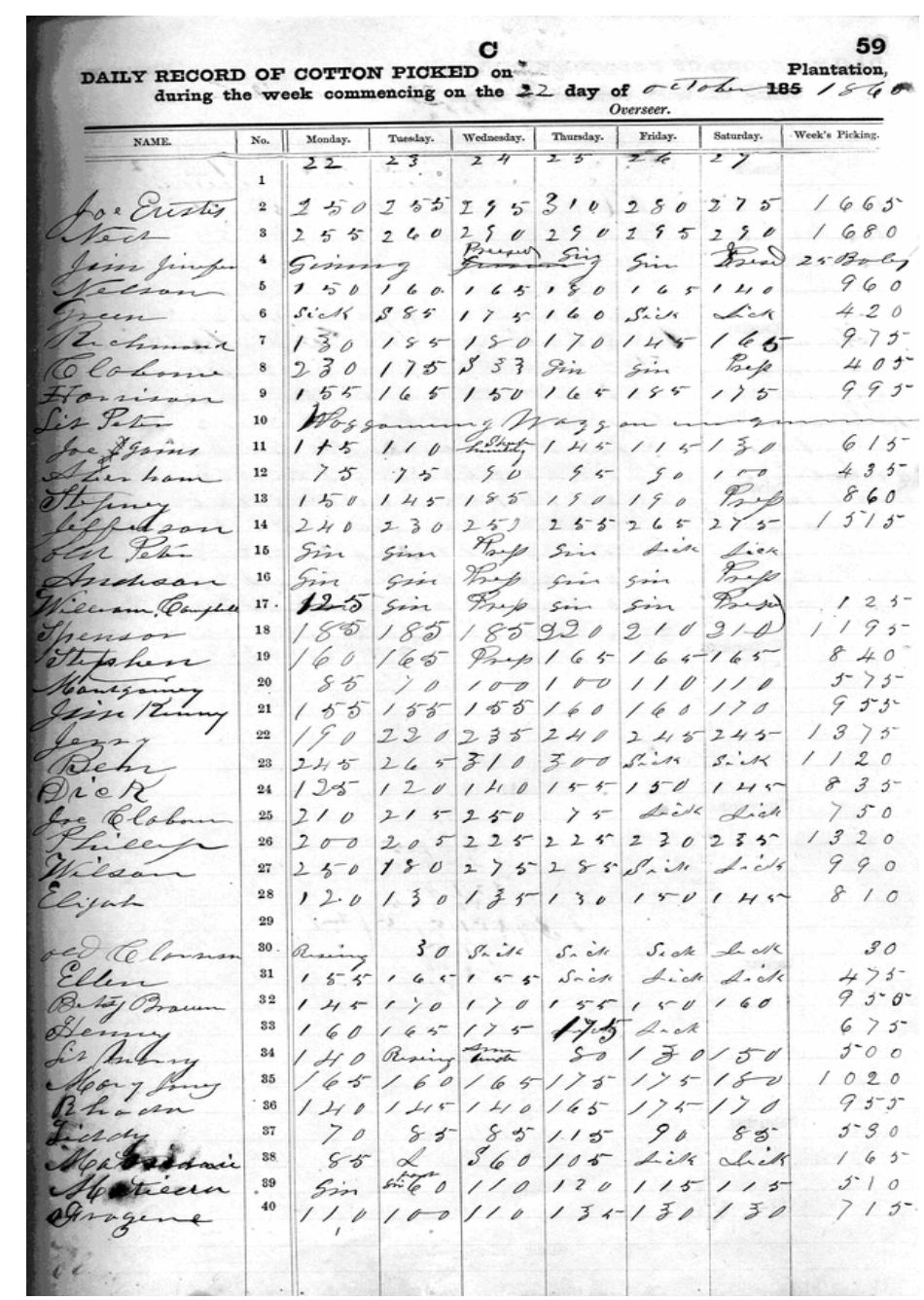

DO DAILY RECORD OF COTTON PTOKED

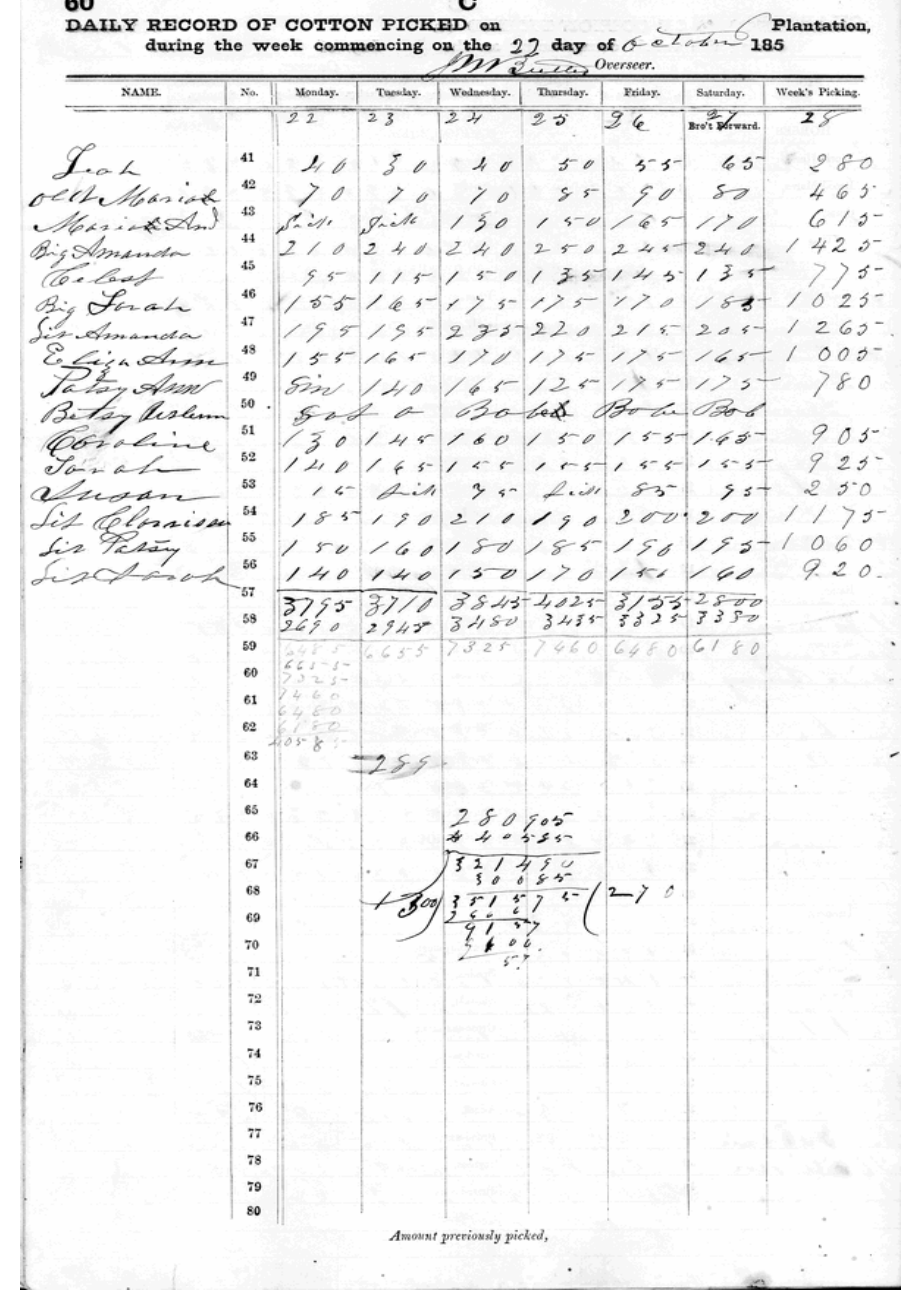

Source: Eustatia Plantation, Mississippi, Account Book 1861, Ohio Historical Center Archives. 
Figure 4: Geographic Distribution of Plantation-Year Observations

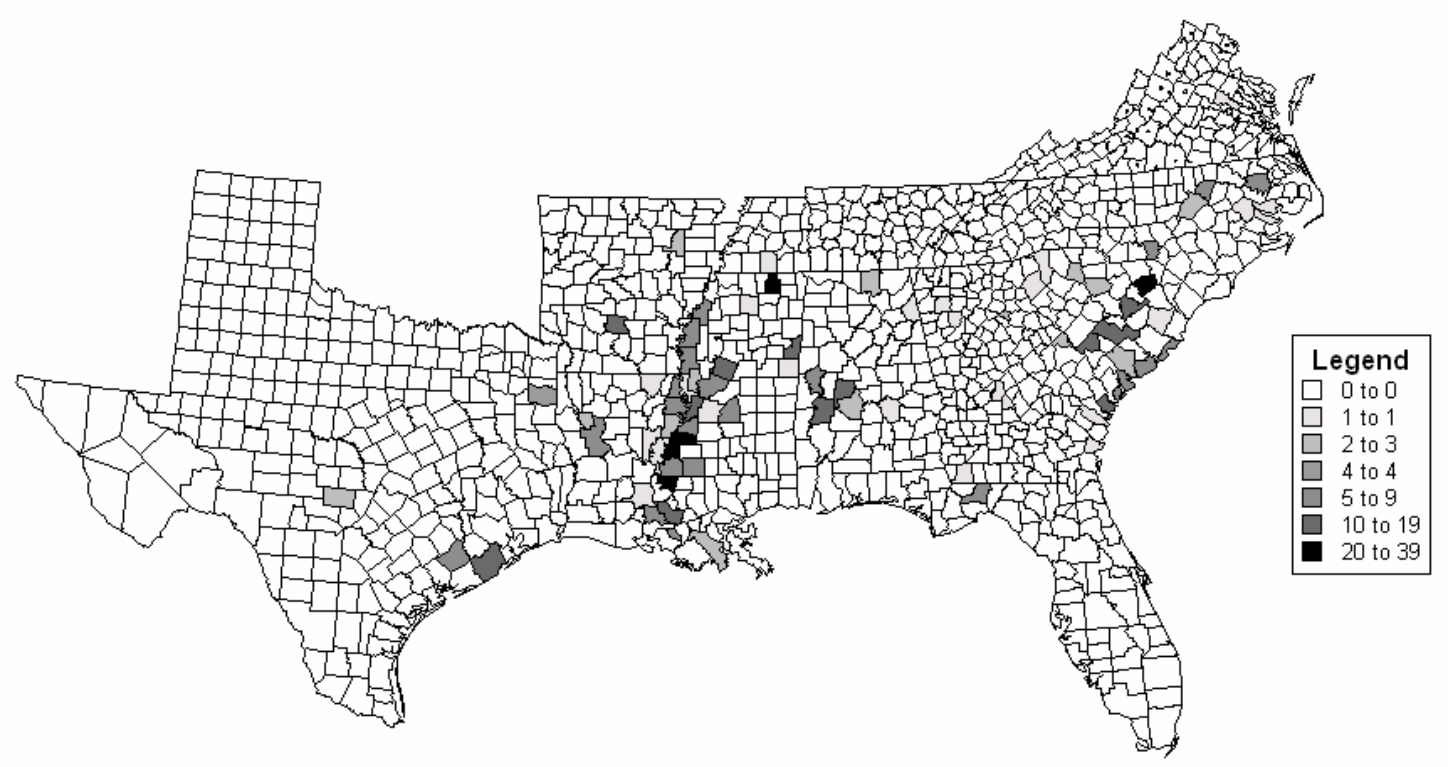

Source: Compiled from Slave Cotton Plantation Dataset, 2008. 
Figure 5: Mean Daily Picking Rates by Plantations, 1801-1862

Panel A: Upland Cotton ( $\mathrm{N}=474)$

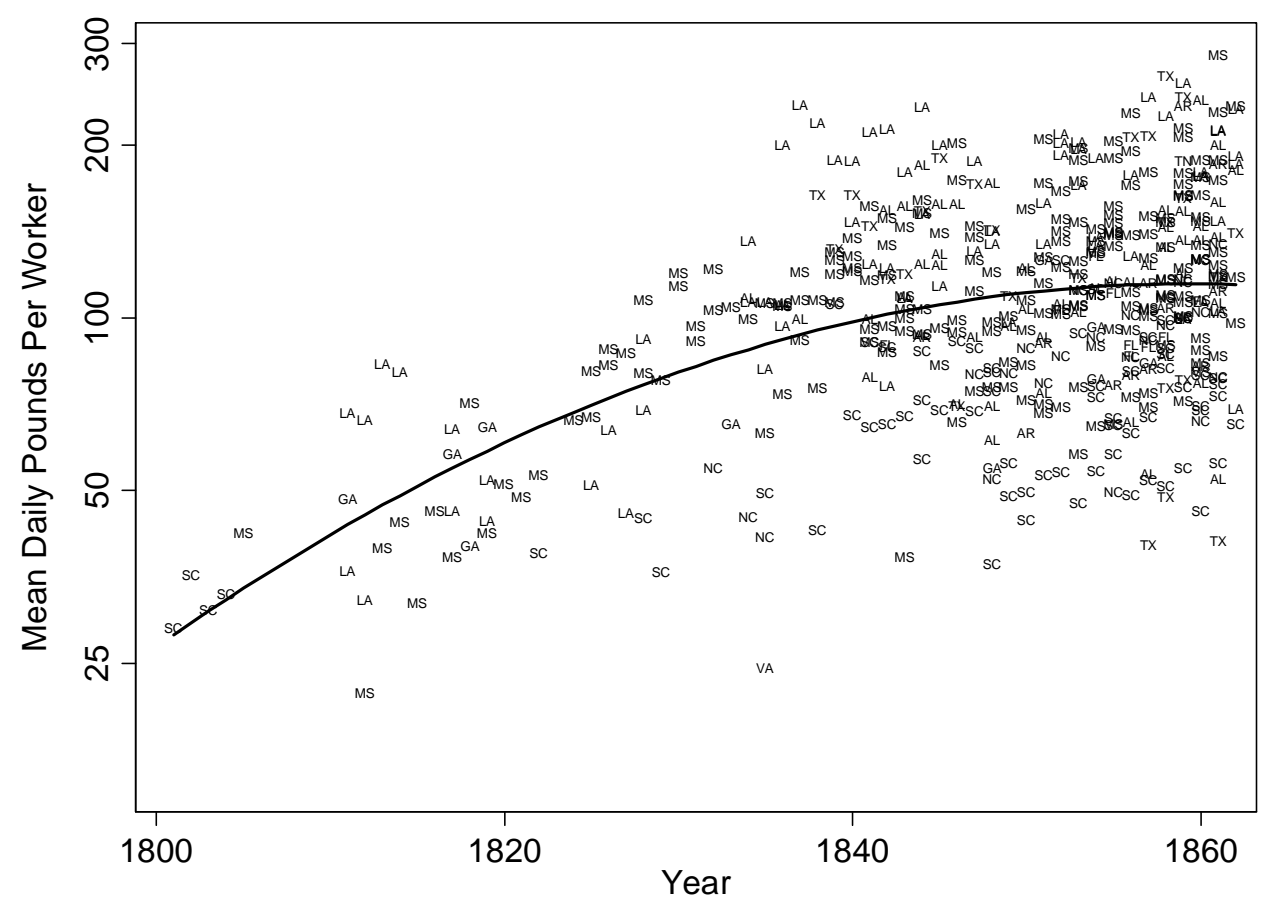

Panel B: Sea Island Cotton $(\mathrm{N}=35)$

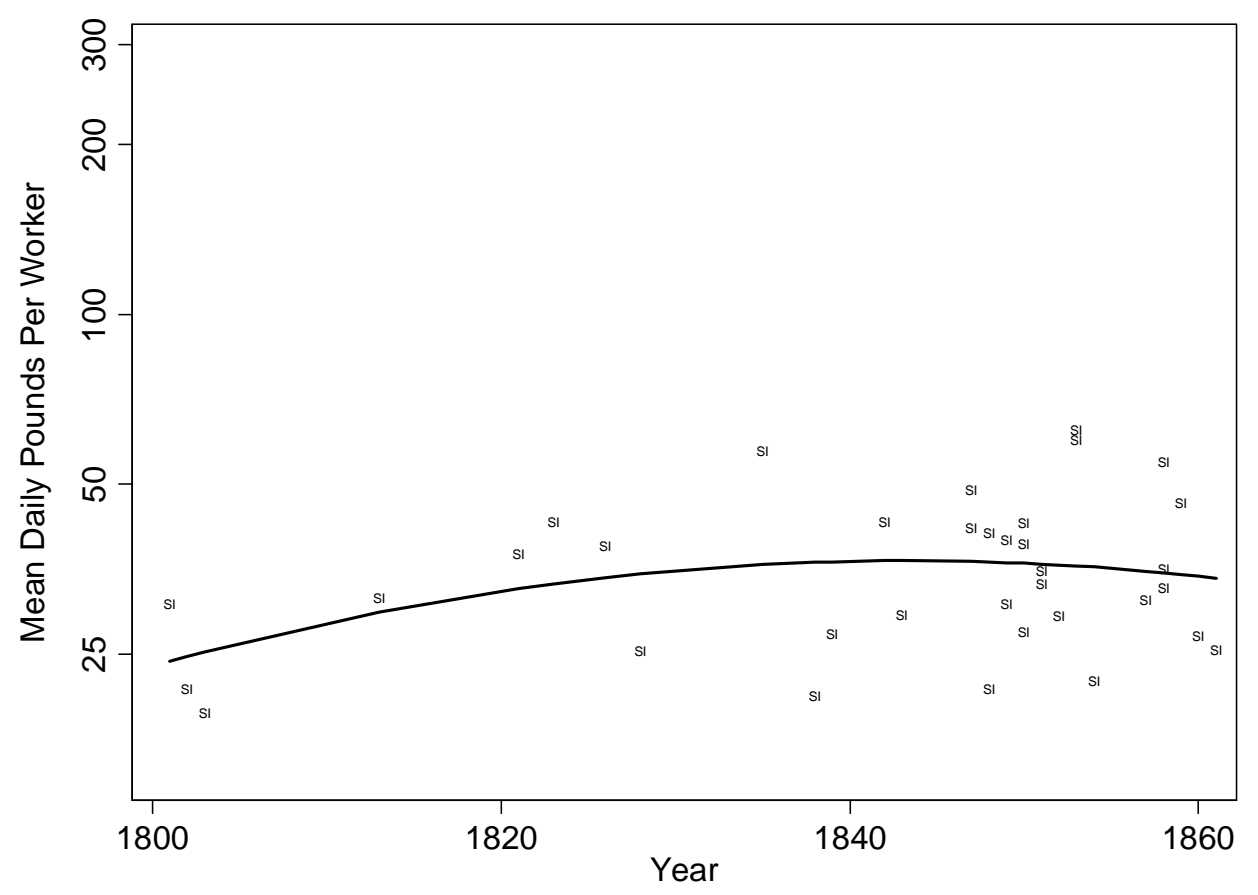

Source: Compiled from Slave Cotton Plantation Dataset, 2008. 
Figure 6: Regional Distribution of U.S. Cotton Production, 1800-1860

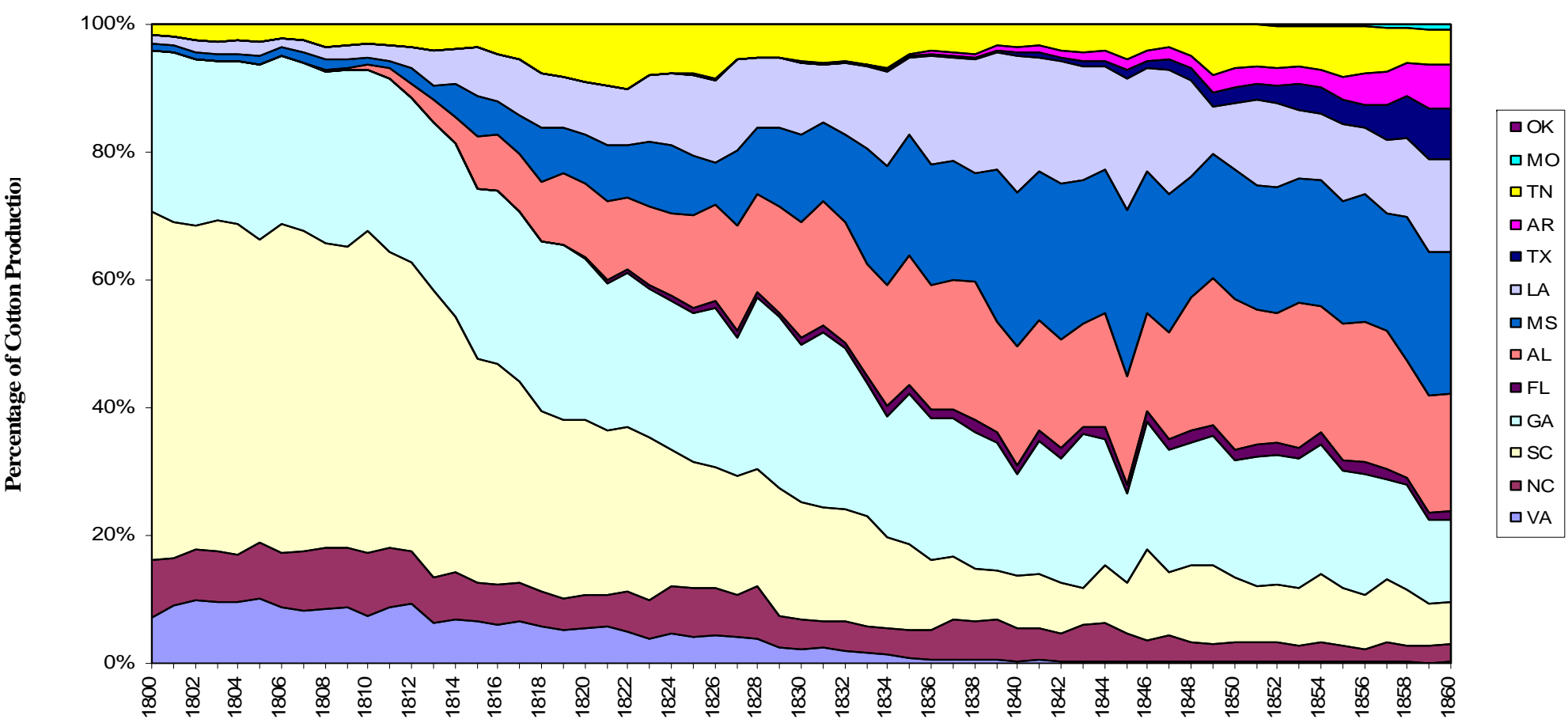

Source: Watkins, King Cotton, passim. 
Figure 7: Geographic Breakdown of Upland Cotton Picking Rates

Panel A: Old South $(\mathrm{N}=103)$

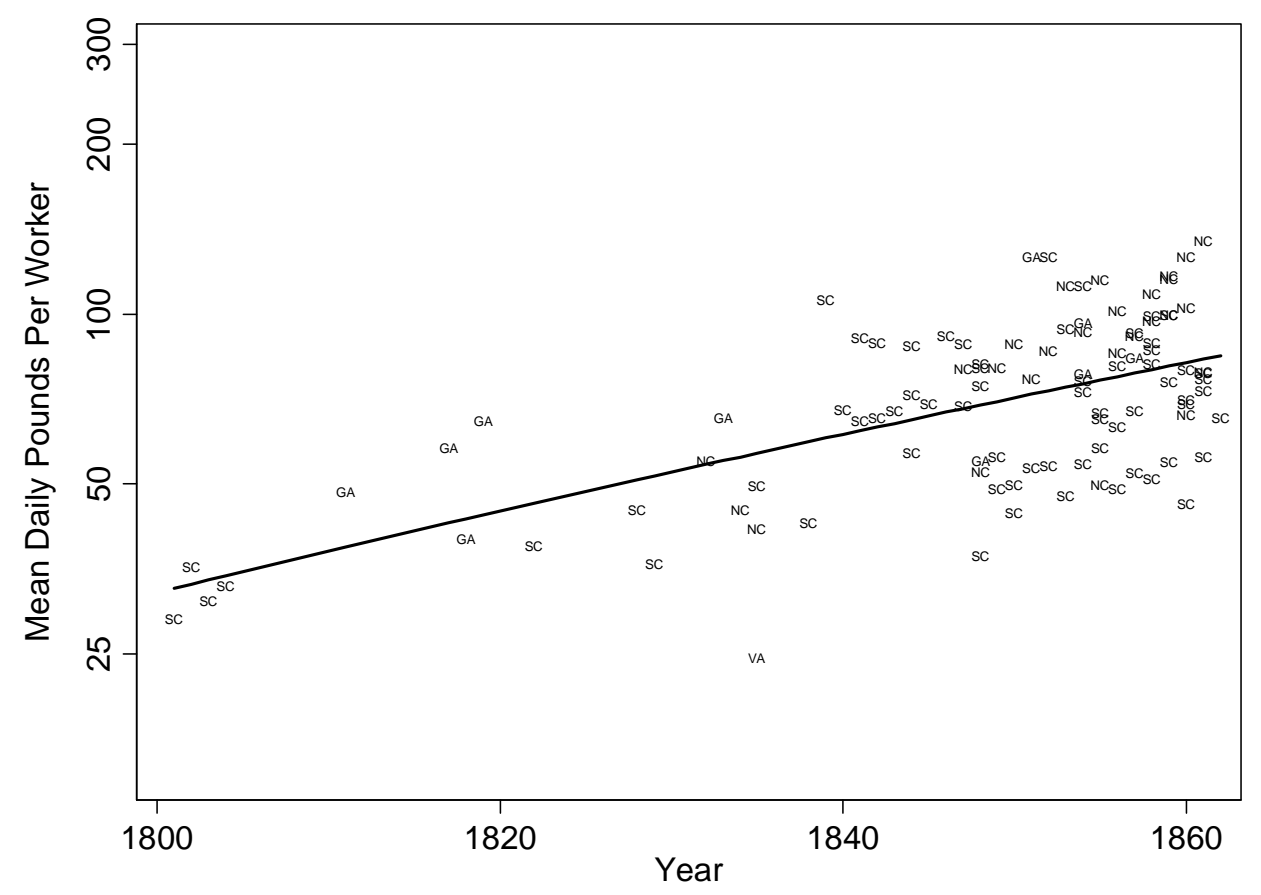

Panel B: New South $(\mathrm{N}=371)$

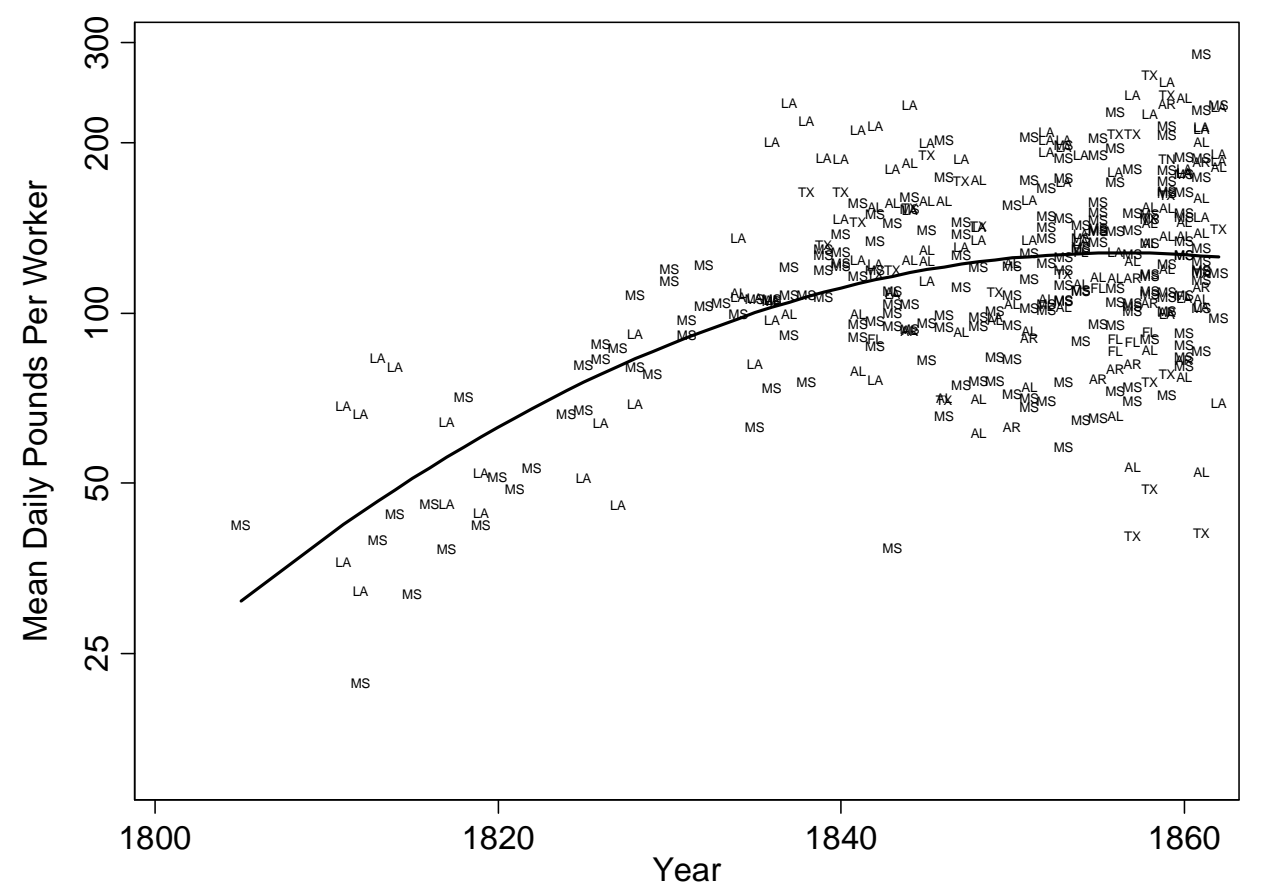

Source: Compiled from Slave Cotton Plantation Dataset, 2008. 
Appendix: References - Used in Construction of Slave Cotton Plantation Dataset, 2008

$\underline{\text { Archives \& Collections }}$

Alabama Department of Archives and History (Montgomery, AL).

Hall Family. Papers, 1785-1923. LPR39.

Waldwick Plantation Records, 1834-1971. LPR174.

Arizona Historical Society Library and Archives (Tuscon, AZ).

Dinsmore Family. Papers, 1731-1978. MS1016.

Birmingham Public Library, Archives Department (Birmingham, AL).

Faunsdale Plantation Papers.

Center for American History, University of Texas (Austin, TX).

Leyendecker Family. Papers, 1817-1981.

Rogillio Family. Papers, 1821-1933.

Darlington Historical Society (Darlington, SC).

Wilds, Peter. Collection.

Department of Archives and Special Collections, J.D. Williams Library, University of Mississippi (University, MS).

Locust Grove Slave Ledger. MUM00275.

Florida Historical Society Library (Cocoa, FL).

El Destino Plantation Papers, 1786-1938. Mss. 2001-02.

Georgia Department of Archives and History (Morrow, GA).

Butts, Elijah. Plantation Account Book, 1843-1865 (bulk 1843-1846, 1855-1864).

Conley, Benjamin. Papers, 1839-1875, 1880, and n.d.

Curry, Duncan. Major Duncan Curry Business Papers.

Everett, Josiah. Daybook.

Fincher, William J. Diary.

Lester, John Vickers. School Roll Book, 1856.

Smith, Archibald. Family Papers, 1670, 1696, 1737-1985, and n.d.

Houghton Library, Harvard University (Cambridge, MA).

Palfrey Family. Papers. MS 1704-1704.9, 1704.11-1704.21.

Huie Library, Henderson State University (Arkadelphia, AR).

Bozeman Plantation Journal. ARK F 417.C53 B69.

Huntington Library, Art Collections, and Botanical Gardens (San Marino, CA).

Postlethwaite Family Papers. Mss. HU 28847.

Jarrett Learning Center, East Texas Baptist University (Marshall, TX).

Webster, John B. Plantation Journal.

Louisiana and Lower Mississippi Valley Collections, Louisiana State University Libraries (Baton Rouge, LA).

Capell Family. Papers. Mss. 56, 257, 1751, 2501, 2597.

Jenkins, John C. Family Papers. Mss. 141,142,184,187.

Liddell, Moses and St. John Richardson. Family Papers. Mss. 531.

Monette, James. Day Book and Diary. Mss. 0590. 
Snyder, Alonzo. Papers. Mss. 655.

Steward, Robert. Family Account Books. Mss. 404, 4732.

Manuscript, Archives and Rare Book Library, Emory University (Atlanta, GA).

Graves Family. Papers, 1818-1939 (bulk 1836-1910). Coll. 327.

Manuscripts Department, Library of the University of North Carolina (Chapel Hill, NC).

Newstead Plantation Records. MS 2339.

Microform Collection, Davis Library, University of North Carolina (Chapel Hill, NC).

Dent, John Horry. Farm Journals and Account Books, 1840-1892.

Mississippi Department of Archives and History (Jackson, MS).

Allen, James. Plantation Book. Z/0014.000, reel 35978.

Anonymous Plantation Diary. Z/0024.000, reel 37134.

Ayres Family. Papers. Z/1873.000, Reel 36543.

Denton, William A. Diary. Z/2028.000, Archival Reading Room.

Griffith, B. W. and Rondo A. Westbrook. Papers. Z/1287.000; Box 1; Folder 10.

Helm, Thomas E. Plantation Record Book. Z/0859.000, reel 35998.

Magruder, James Trueman, Jr. Mercantile Ledgers [manuscript]. Z/1995.000.

McGehee Family. Papers, 1854-1874. Z/0899.000.

Metcalfe Family. Papers. Z/1874.000, reels 36547-48.

Metcalfe, Frederick Augustus. Papers. Z/1843.000.

Parker, Houston Huling. Papers. Z/1710.000, reel 36319.

Rabb Family. Plantation Journal. Z/1985.000.

Rainwater. Z/0052.000.

Shields, William F. Papers. Z/0040.000.

Spencer, Horatio Nelson. Papers. Z/0196.000, cotton book.

Surget-McKittrick-Macneil Family. Papers. Z/1795.000, reel 36215.

Sykes, Columbus. Papers. Z/0012.000.

Taylor Family. Plantation Ledger. Z/2260.000.

Wheless, Frederick W. Plantation Journal. Z/1986.000.

Missouri Historical Society (St. Louis, MO).

Jones Family. Plantation Records.

North Carolina Department of Archives and History (Raleigh, NC).

Clark, James F. Plantation Book. MARS ID 539.

Mial, Alonzo T. and Millard. MARS ID 2968.

Ohio Historical Center Archives Library (Columbus, $\mathrm{OH}$ ).

Eustatia Plantation, Mississippi, Account Book. Vol. 649.

Rare Book, Manuscript, and Special Collections Library, Duke University (Durham, NC).

Dromgoole, George Coke, and Richard B. Robinson. Papers, 1767-1974.

Law, Willam. Papers, 1761-1890.

Nutt, Haller. Papers.

Sims, Joseph Starke. Papers, 1819-1903.

Sydnor, Charles S. Papers, 1729-1978 and n.d. (bulk 1923-1954).

South Carolina Historical Society (Charleston, SC).

Coffin, Ebenezer, 1765-1817. Coffin Point Plantation Journal, 1800-1816. 34/199.

Smith, William Wragg, 1808-1875. William Wragg Smith Papers, 1803-1859. 1118.03.01.

Webb, Daniel Cannon, 1782-1850. Daniel Cannon Webb Plantation Journals, 1817-1850. 1154.

South Caroliniana Library, University of South Carolina (Columbia, SC). 
Aiken, David. Farmers' Diary, 1855-58. Coll. 14.

Anonymous Plantation Records. Acc. 1001.

Blewett, Thomas G. Papers. Acc. 1001.

Charles and Company (Darlington County, S.C.). Records. Acc. 1813.

Coleman, Feaster, and Faucette Families. Papers. Acc. 12663.

Crosswell, J.R. Account Book. Acc. 1001.

Guignard Family. Papers. Acc. 1001, 1425, 1938, 2527, 2630, 14120.

Guild Family. Account Book.

Huey Family. Papers. Acc. 5137.

Osteen, Thomas H. Papers. Acc. 9450.

Taylor, Washington. Journal, 1835-1855.

Watts, James Washington. Papers. Acc. 6010.

Southern Historical Collection, Manuscripts Department, Library of the University of North Carolina (Chapel Hill, NC).

Arrington, Archibald Hunter. Papers. 3240.

Ballard, Rice C. Papers, 1822-1888. 4580.

Bills, John Houston. Papers. 2245.

De Saussure, Louis M. Journal. 2251-z.

Ervin, William Ethelbert. Diaries. 247.

Gould. William Proctor. Diary. 1192.

Grimes Family. Papers. 3357.

Hamilton, W. S. Papers. 1471.

Lewis Plantation Records. 2528.

Massenburg, Nicholas Bryor. Papers, 1834-1851. 908.

Postell, James P. Kelvin Grove Plantation Book. 2771.

Whitmore, Charles. Plantation Journal. M-2046.

Yancey, Benjamin Cudworth. Papers. 2594.

Special Collections, Clemson Unviersity Libraries (Clemson, SC).

Overseer's Daybook (Westwood Plantation). Mss. 230.

Special Collections, Library of the University of Arkansas (Fayetteville, AR).

Currie Family. Papers. MC713.

Currie. James B. Ledger, 1851-1869.

Shugart Plantation Records. MC1075.

Special Collections, University Libraries, Virginia Polytechnic Institute \& State University, (Blacksburg, VA).

Overseer's Journal, 1853-1861. Ms1994-010.

Special Collections Department, Florida State University Libraries (Tallahassee, FL).

Plantation Record Book, 1836-1841. Mss. 1-10.

Sturdivant Hall Museum (Selma, AL).

Sturdivant Hall Plantation Records.

University of California, Berkeley, Library (Berkeley, CA).

Plantation Journal for "The Mountain", Mississippi [1852-64]. MICROFILM.5640.HT.

University of Virginia Library (Charlottesville, VA).

Hillyer Family. Papers, 1797-1860. Acc. 2130.

Virginia Historical Society (Richmond, VA).

Mason Family. Papers. MSS1M3816c. 
W.S. Hoole Special Collections Library, University of Alabama (Tuscaloosa, AL).

Davis, Hugh. Papers. MS1611.

Sturdivant Hall Papers.

Archives \& Collections Consulted Via:

Stampp, Kenneth M., ed. Records of Ante-bellum Southern Plantations from the Revolution through the Civil War [Microfilm]. Frederick, MD: University Publications of America, 1985-2000.

Series A, Selections from the South Caroliniana Library, University of South Carolina.

Caleb Coker (1802-1869) Plantation Book, 1856-1861. RASP, Ser. A, pt. 2, reel 3.

James D. Trezevant Plantation Diary and Records, 1845-1858. RASP, Ser. A, pt. 2, reel 3.

Mary Hart Means (1835-1916) Papers, 1846-1865. RASP, Ser. A, pt. 2, reel 4.

Papers of James Henry Hammond, 1795-1865. RASP, Ser. A, pt. 1, reels 1-15.

Samuel Porcher Gaillard (1811-1880) Plantation Journals, 1835-1871. RASP, Ser. A, pt. 2, reels 1-2.

Thomas Cassels Law (1811-1888) Papers, 1810-1865. RASP, Ser. A, pt. 2, reels 7-8.

Series B, Selections from the South Carolina Historical Society.

Thomas Walter Peyre Plantation Journal, 1812-1851. RASP, Ser. B, Reel 5.

Series F, Selections from the Manuscript Department, Duke University Library.

Duncan and Dugal McCall Plantation Journals, 1832-1854. RASP, Ser. F, pt. 1, reels 4-5.

Haller Nutt Papers, 1846-1860, and Journal of Araby Plantation, 1843-1850. RASP, Ser. F, pt. 1, reel 1-2.

Joseph M. Jaynes Plantation Journals, 1854-1860. RASP, Ser. F, pt. 1, reel 1.

Rockingham Plantation Journal, 1828-1829. RASP, Ser. F, pt. 2, reel 8.

Series G, Selections from the Barker Texas History Center, University of Texas at Austin.

Barnes-Willis Family Papers, 1783-1840. RASP, Ser. G, pt. 5, reels 15-17.

Canebrake Plantation Record Books, 1856-1868. RASP, Ser. G, pt. 1, reel 11.

Green C. Duncan Papers, 1850-1865. RASP, Ser. G, pt. 1, reel 33.

James Franklin Perry and Stephen Samuel Perry Papers, 1786-1895. RASP, Ser. G, pt. 1, reels 12-31.

John P. Bolton Account Book and Plantation Records, 1853-1863. RASP, Ser. G, pt. 1, reel 33.

Kiger Family Papers, 1820-1885. RASP, Ser. G, pt. 5, reels 25-28.

Series H, Selections from the Howard-Tilton Library, Tulane University, and the Louisiana State Museum Archives.

Bonaventure Plantation Book, 1850-1851. RASP, Ser. H, reel 1.

David Rees Papers, 1803-1835. RASP, Ser. H, reels 29-30.

Series I, Selections from Louisiana State University.

Alexander Blanche Plantation Journal, 1851-1856. RASP, Ser. I, pt. 3, reel 14.

John H. Randolph Papers, 1822-1865. RASP, Ser. I, pt. 1, reels 14-15.

Joseph Toole Robinson Papers, 1830s and 1853-1861. RASP, Ser. I, pt. 2, reel 20.

LeBlanc Family Papers, 1812-1866. RASP, Ser. I, pt. 2, reel 17.

Lewis Stirling and Family Papers, 1784-1865. RASP, Ser. I, pt. 2, reels 21-25.

Nathaniel Evans and Family Papers, 1791-1865. RASP, Ser. I, pt. 2, reels 1-10.

Pre Aux Cleres Plantation Record Books, 1852-1854. RASP, Ser. I, pt. 2, reel 19.

Series J, Selections from the Southern Historical Collection, Manuscripts Department, Library of the University of North Carolina at Chapel Hill.

Benjamin Franklin Little Papers, 1806-1935. RASP, Ser. J, pt. 13, reels 38-39.

Branch Family Papers, 1788-1866. RASP, Ser. J, pt. 4, reels 45-47.

Francis Terry Leak Papers, 1839-1865. RASP, Ser. J, pt. 6, reels 24-27.

George J. Kollock Plantation Books, 1837-1861 RASP, Ser. J, pt. 4, reels 2-3.

Jackson and Prince Family Papers, 1784-1880. RASP, Ser. J, pt. 4, reels 25-36.

John Durant Ashmore Plantation Journal, 1853-1859. RASP, Ser. J, pt. 3, reel 27. 
John Edwin Fripp Papers, 1817-1905. RASP, Ser. J, pt. 3, reel 25.

Nicholas, Bryor Massenburg Papers, 1834-1851. RASP, Ser. J, pt. 13, reels 1-2.

Phanor Prudhomme Papers, 1804-1940. RASP, Ser. J, pt. 5, reels 15-17.

Ruffin, Roulhac, and Hamilton Family Papers (James H. Ruffin Plantation Records), 1841-1848. RASP, Ser. J, pt. 7, reel 7.

Wyche and Otey Family Papers, 1824-1900 and 1935-1936. RASP, Ser. J, pt. 7, reels 9-12.

Series M, Selections from the Virginia Historical Society.

Baskervill Family Papers, 1747-1928. RASP, Ser. M, pt. 5, reels 2-8.

Bassett Family Papers, 1728-1923. RASP, Ser. M, pt. 3, reels 1-4.

Mason Family Papers, 1789-1965. RASP, Ser. M, pt. 5, reels 36-46.

Series N, Selections from the Mississippi Department of Archives and History.

Aventine Plantation Diary, 1857-1860. RASP, Ser. N, reel 1.

Charles Clark and Family Collection, 1810-1892. RASP, Ser. N, reels 4-5.

Elley Plantation Book, 1855-1856. Series N, Reel 10

James T. Magruder Account Book and Plantation Journal, 1796-1818. RASP, Ser. N, reel 12.

James T. Magruder Cotton Book, 1818-1830. RASP, Ser. N, reel 12.

Killona Plantation Journals, 1836-[1840]. RASP, Ser. N, reel 12.

Levin Covington Diary, 1825-1845. RASP, Ser. N, reel 5.

Panther Burn Journals, 1859-1883. RASP, Ser. N, reel 12.

Walter Wade Plantation Diaries, 1834-1854. RASP, Ser. N, reel 18.

Archives \& Collections Consulted Via:

Berlin, Ira, ed. Records of Southern Plantations from Emancipation to the Great Migration. [Microfilm]. Bethesda, MD: University Publications of America, 2001.

Series A. Selections from the Rare Book, Manuscript, and Special Collections Library, Duke University.

David Miller Carter Papers, 1858-1903. Ser. A, pt. 2, reel 4.

Single Publications

Davis, Edwin A., ed. Plantation Life in the Florida Parishes of Louisiana, 1836-1846, As Reflected in the Diary of Bennet H. Barrow. New York: AMS Press, 1967.

Kilpatrick, Dr. "Historical and Statistical Collections of Louisiana: The Parish of Catahoula, Part 2." De Bow's Review 12, no. 6 (1852): 631-46.

“The Plantation Journal of John B. Webster, February 17, 1858-November 5, 1859,” Southwestern Historical Quarterly 84, no. 1 (July 1980).

Whartenby, Franklee Gilbert. Land and Labor Productivity in United States Cotton Production, 1800-1840. New York: Arno Press, 1977. 